\title{
Evidence for Two Stages of Mineralization in West Africa’s Largest Gold Deposit: Obuasi, Ghana
}

\author{
Denis Fougerouse, ${ }^{1, \dagger}$ Steven Micklethwaite, ${ }^{1}$ Stanislav Ulrich, ${ }^{2}$ John Miller, ${ }^{1}$ \\ Bélinda Godel, ${ }^{3}$ David T. Adams, ${ }^{4}$ and T. Campbell McCuaig ${ }^{1,5}$ \\ ${ }^{1}$ Centre for Exploration Targeting, School of Earth and Environment, University of Western Australia, M006, \\ 35 Stirling Highway, Crawley, Western Australia 6009, Australia \\ 2 AngloGold Ashanti Ltd., Assets Development Brownfields, 140 St George Terrace, Perth, Western Australia 6000, Australia \\ ${ }^{3}$ CSIRO Earth Science and Resource Engineering, Australian Resources Research Centre, 26 Dick Perry Avenue, \\ Kensington, 6151, Western Australia, Australia \\ ${ }^{4}$ Centre for Microscopy, Characterisation and Analysis M010, University of Western Australia, \\ 35 Stirling Highway, Crawley, Western Australia 6009, Australia \\ ${ }^{5}$ ARC Centre of Excellence for Core to Crust Fluid Systems, School of Earth and Environment, \\ University of Western Australia, M006, 35 Stirling Highway, Crawley, Western Australia 6009, Australia
}

\begin{abstract}
The supergiant Obuasi gold deposit is the largest deposit in the Paleoproterozoic Birimian terranes of West Africa with $62 \mathrm{Moz}$ of gold (past production + resources). The deposit is hosted in the Paleoproterozoic Kumasi Group sedimentary rocks composed of carbonaceous phyllites, slates, psammites, and volcaniclastic rocks intruded by different generations of felsic dikes and granites. A three-stage deformation history is defined for the district. The $\mathrm{D} 1_{\mathrm{Ob}}$ stage is weakly recorded in the sedimentary rocks as a layer-parallel fabric and indicates that bedding parallel shearing occurred during the early stage of deformation at Obuasi. The D2 $\mathrm{Ob}$ is the main deformation stage affecting the Obuasi district and corresponds to a NW-SE shortening. Tight to isoclinal folding, as well as intense subhorizontal stretching, occurred during $\mathrm{D} 2 \mathrm{Ob}$, parallel with the plane of a pervasive NE-striking subvertical foliation $\left(\mathrm{S} 2_{\mathrm{Ob}}\right)$. Finally, a N-S shortening event $\left(\mathrm{D} 3_{\mathrm{Ob}}\right)$ refolded previously formed structures and formed a distinct ENE-striking, variably dipping S3ob cleavage that is domainal in nature throughout the deposit. Two economic styles of mineralization occur at Obuasi and contribute equally to the gold budget. These are (1) gold-bearing sulfides, dominantly arsenopyrite, mainly disseminated in metasedimentary rocks and (2) native gold hosted in quartz veins that are as much as $25 \mathrm{~m}$ wide. Microstructural evidence, such as strain shadows surrounding gold-bearing arsenopyrite parallel with $\mathrm{S} 2_{\mathrm{Ob}}$, but folded by $\mathrm{S} 3_{\mathrm{Ob}}$, indicates that the sulfides were formed during D2 $\mathrm{Ob}$. Concentrations of as much as $700 \mathrm{ppm} \mathrm{Au}$ are present in the epitaxial growth zones of the arsenopyrite grains. Although the large mineralized quartz veins are boudinaged and refolded (indicating their formation during $\mathrm{D} 2_{\mathrm{Ob}}$ ), field and microanalytical observations demonstrate that the gold in the veins is hosted in microcracks controlled by $\mathrm{D} 3 \mathrm{ob}$, where the $\mathrm{S} 33_{\mathrm{ob}}$ cleavage crosscuts the quartz veins in the main ore zones. Thus, these observations constitute the first evidence for multiple stages of gold deposition at the Obuasi deposit. Futhermore, three-dimensional modeling of stratigraphy, structure, and gold orebodies highlights three major controls on oreshoot location, which are (1) contacts between volcaniclastic units and pre- $\mathrm{D}_{1}$ felsic dikes, (2) fault intersections, and (3) F 3 ob fold hinges. The maximum age for the older disseminated gold event is given by the age of the granites at $2105 \pm 2 \mathrm{Ma}$, which is within error of hydrothermal rutile in the granites of $2098 \pm 7 \mathrm{Ma}$; the absolute age of the younger gold event is not known.
\end{abstract}

\section{Introduction}

The Obuasi deposit is the largest gold deposit hosted in the Birimian of West Africa (Fig. 1). The cumulative past production and resources total 62 million ounces (Moz) of gold as of 2014 (AngloGold-Ashanti, 2014), hosted in both goldbearing sulfides disseminated in metasedimentary rocks and visible gold in large quartz veins. Although there have been a number of studies of the Obuasi deposit (Junner, 1932; Wilson, 1972; Amanor, 1979; Gyapong, 1980; Bowell et al., 1990; Schwartz et al., 1992; Blenkinsop et al., 1994; Bowell, 1994; Höhndorf et al., 1994; Oberthür et al., 1994, 1997; Klemd et al., 1996; Mumm et al., 1997; Yao and Robb, 2000; Yao et al., 2001; Allibone et al., 2002), there remain two contrasting interpretations on the timing of mineralization at

\footnotetext{
† Corresponding author: e-mail, denis.fougerouse@curtin.edu.au
}

Obuasi based on careful documentation of the geology of the deposit.

The first model, based on petrological and structural observations, proposed that the two contrasting types of mineralization, the gold-bearing quartz veins and auriferous disseminated sulfide ores, can be explained by the system evolving progressively during a single event from ductile to brittle deformation (Blenkinsop et al., 1994; Oberthür et al., 1994). The second model, based mainly on regional, open-pit, and underground mapping and detailed field observations, described a multiphase deformation history, but attributed the majority of mineralization in both the veins and the wall rocks to late sinistral reactivation of an earlier fault system (Allibone et al., 2002).

This paper focuses specifically on reexamining the relative timing of mineralization at Obuasi as part of a larger study to 


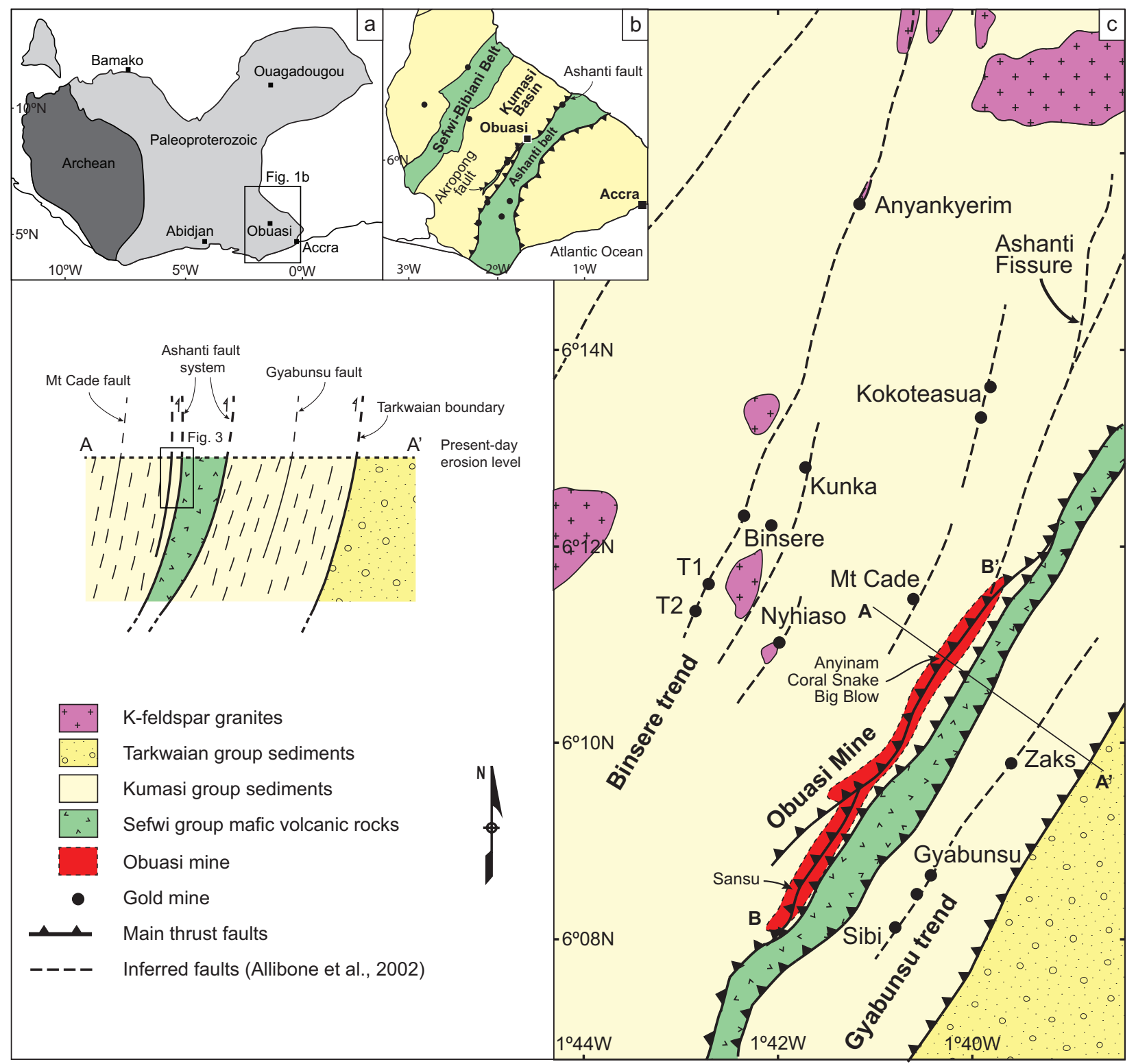

Fig. 1. a. Schematic overview of the geology of the southern part of the West African craton. Position of (b) is indicated. b. Simplified Birimian geology of Ghana with alternating greenstone belts and sedimentary basins. Obuasi is located in the Kumasi volcano-sedimentary basin, close to the contact with the Ashanti belt in the vicinity of an intersection between two major faults, the Akropong and Ashanti faults. c. Obuasi district geology. The Binsere and Gyabunsu trends and the main Obuasi deposit share the same strike (modified from Allibone et al., 2012). Positions of cross section A-A' and long section B-B' (Fig. 7) are indicated. Cross section A-A' shows one possible interpretation of the structural architecture of the district. The location of Figure 3 is indicated on the cross section.

determine the controls on the genesis, location, and geometry of the gold mineralization. Timing of mineralization is critical to understanding oreshoot controls with respect to the structural sequence in order to be able to define an exploration strategy. This study provides analysis of existing and new field data made available by more than 10 years of additional mine development since the last study (Allibone et al., 2002). We present observations integrated across different scales, derived from structural field mapping, deformation fabrics, ore mineralogy, and alteration petrography. Microanalytical techniques employed include scanning electron microscopy (SEM), electron microprobe measurements, and high-resolution X-ray computed tomography. In the first part of the paper, we develop a structural framework and reassess the previous structural models (Blenkinsop et al., 1994; Allibone et al., 2002). In the second part, we examine the timing of mineralization using the developed structural framework. We finally discuss the significance of our results in a broader context by comparing Obuasi with new regional studies in West Africa (Miller et al., unpub. data) and other giant gold deposits worldwide.

\section{Geologic Background}

West African basement rocks consist of the following main lithostratigraphic units (oldest to youngest): (1) high-grade 
basement gneisses of the Archean Man-Leo shield; (2) Paleoproterozoic Birimian volcanic greenstone belts (Sefwi Group); (3) Paleoproterozoic Birimian volcano-sedimentary rocks (Kumasi Group), in which the Obuasi deposit is hosted; and (3) Paleoproterozoic Tarkwaian Group metasedimentary rocks composed of sandstone and conglomerates (Pigois et al., 2003). Several generations of granitoids intrude these rocks (Figs. 1, 2; Junner, 1935; Leube and Hirdes, 1986; Leube et al., 1990; Allibone et al., 2002). The oldest rocks in the Obuasi region of southwestern Ghana consist of the Sefwi Group volcanic rocks, which comprise metabasalts, mafic volcaniclastic rocks and rhyolites, and the synchronous tonalite-trondhjemite-granodiorite (TTG) suites of "belt-type granitoids" that were emplaced between 2187 and $2158 \mathrm{Ma}$ (Perrouty et al., 2012). This first Paleoproterozoic deformation is referred to as the Eoeburnean (Perrouty et al., 2012) or Eburnean I (Allibone et al., 2002; Feybesse et al., 2006) orogenic cycle and was followed by a period of regional extension, basin opening, and deposition of sediments of the Kumasi Group. The Kumasi Group rocks include carbonaceous phyllites, graywakes, slates, psammites, and volcano-sedimentary rocks in the Obuasi district, deposited between 2157 and $2125 \mathrm{Ma}$ (Davis et al., 1994; Oberthür et al., 1998; Adadey et al., 2009; Perrouty et al., 2012), with detrital zircon U-Pb ages of $2155 \pm 2 \mathrm{Ma}$, which constrains the maximum depositional age (Davis et al., 1994; Oberthür et al., 1998).

The basinal sedimentary rocks of the Kumasi Group were inverted, metamorphosed to greenschist and amphibolite facies (John et al., 1999), and intruded by granitic to granodioritic rocks (basin-type granitoids), between $2105 \pm 2$ and 2097 $\pm 2 \mathrm{Ma}$ in southwestern Ghana, during what is referred to as the Eburnean (Perrouty et al., 2012) or Eburnean II (Allibone et al., 2002) orogenic cycle. Craton-wide, this cycle spanned the period from 2125 to $1980 \mathrm{Ma}$ (Perrouty et al., 2012). Deformation events discussed in this article all occurred during the younger Eburnean orogenic cycle. Tarkwaian Group rocks could be as young as $2107 \mathrm{Ma}$ (Pigois et al., 2003; Perrouty et al., 2012) and were probably derived from Birimian sedimentary rocks and TTGs uplifted early in the Eburnean II orogenic cycle.

Obuasi, which means "under the rock" in the local Tchi language, is the largest gold deposit discovered in the Obuasi district. Artisanal gold mining at Obuasi has a long history, with

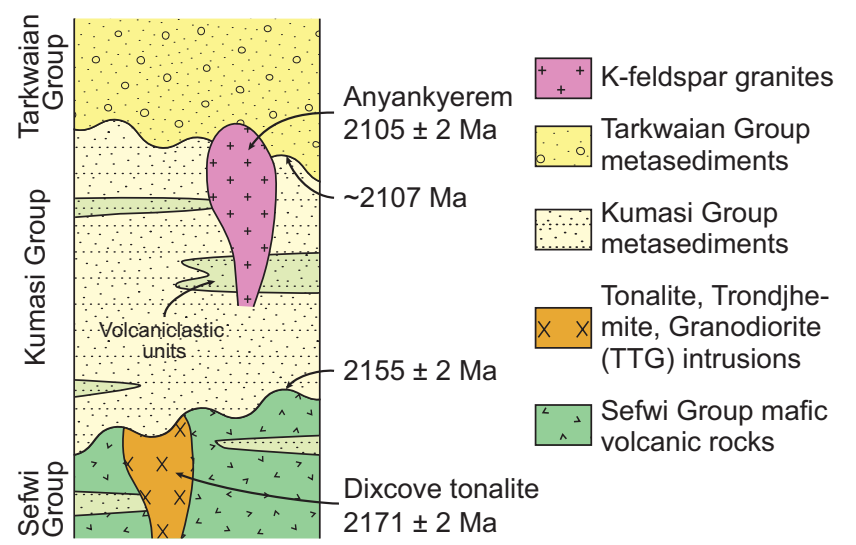

Fig. 2. Simplified stratigraphic column of the Ashanti belt. the local gold seekers, the Galamsey, panning and digging the quartz veins outcropping at the surface since before the $15^{\text {th }}$ century. Industrial mining officially started in 1897 with the establishment of the Ashanti Goldfields Corporation. To date, 20 individual ore shoots have been found distributed along the 8-km strike length of the deposit; some reaching depths of $>1.6 \mathrm{~km}$, which is the deepest level of mining. More than 15 satellite deposits, defining the Obuasi district, are located within parallel trends west and east of the Obuasi deposit and show a range of different styles of mineralization (Fig. 1; Allibone et al., 2002).

The Obuasi district is located in the Kumasi volcano-sedimentary basin, in rocks of the Kumasi Group close to the contact with the Ashanti greenstone belt, which itself comprises rocks of the Sefwi Group. The district is located near a concealed intersection between two major faults, the Ashanti and Akropong thrust faults (Perrouty et al., 2012).

Rocks of the Kumasi Group in the Obuasi district most likely represent a metamorphosed turbiditic sequence (Junner, 1932; Amanor, 1979; Gyapong, 1980; Oberthür et al., 1994). Layers of hard, greenish volcano-sedimentary rocks are commonly present adjacent to the mineralized zones. The eastern margin of the Obuasi deposit is bordered by a sliver of mafic volcanic and volcaniclastic rocks probably from the Sefwi Group (Fig. 3; Allibone et al., 2002). Unmineralized and unmetamorphosed dolerite dikes crosscut the ore zone.

In this study, we define the Ashanti fault system as the network of structures and ore shoots in the Obuasi deposit that reaches a maximum of $700 \mathrm{~m}$ in width and is locally classified into discrete highly mineralized substructures (called "fissures" in Obuasi mining terminology), consisting of multiple strands of graphite-rich shear zones (Fig. 3). Carbon isotope analyses of the graphite contained in the shear zones indicate a sedimentary origin for the carbon (Oberthür et al., 1994). These shear zones bound the mineralization, anastomosing and bifurcating along strike and depth. The most highly endowed graphite-rich shear zones in the Ashanti fault system are named the Obuasi, Main Reef, Ashanti, Côte d'Or, Insintsium, lode 3, and Big Blow shear zones.

In and adjacent to each mineralized shear zone, two styles of mineralization coexist: gold-bearing sulfides, dominantly arsenopyrite, that are disseminated in the metasedimentary host rocks and native gold in quartz veins (Oberthür et al., 1994). The gold-bearing sulfides account for approximately $60 \%$ of the gold production at Obuasi (Milési et al., 1991). Commonly, the steeply dipping ore zones, which are as much as $50 \mathrm{~m}$ wide, comprise one or several thick mineralized quartz veins and sulfide ores disseminated between two graphitic shears. The sedimentary bedding is tightly folded and several generations of structural fabric can be observed (Blenkinsop et al., 1994; Allibone et al., 2002).

Two other mineralized trends in the Obuasi district, located west and east of the Obuasi deposit, share the same strike as the Ashanti fault system (Fig. 1). The Binsere trend, located $5 \mathrm{~km}$ to the west, contains granite-hosted deposits, whereas mineralization in the eastern Gyabunsu trend is hosted in metasedimentary rocks. The mineralization in the Binsere trend is predominantly contained in gold-bearing sulfides and goldrich quartz veins, confined to hydrothermally altered granites and their adjacent metasedimentary rocks (Anyankyerim, 
West

East

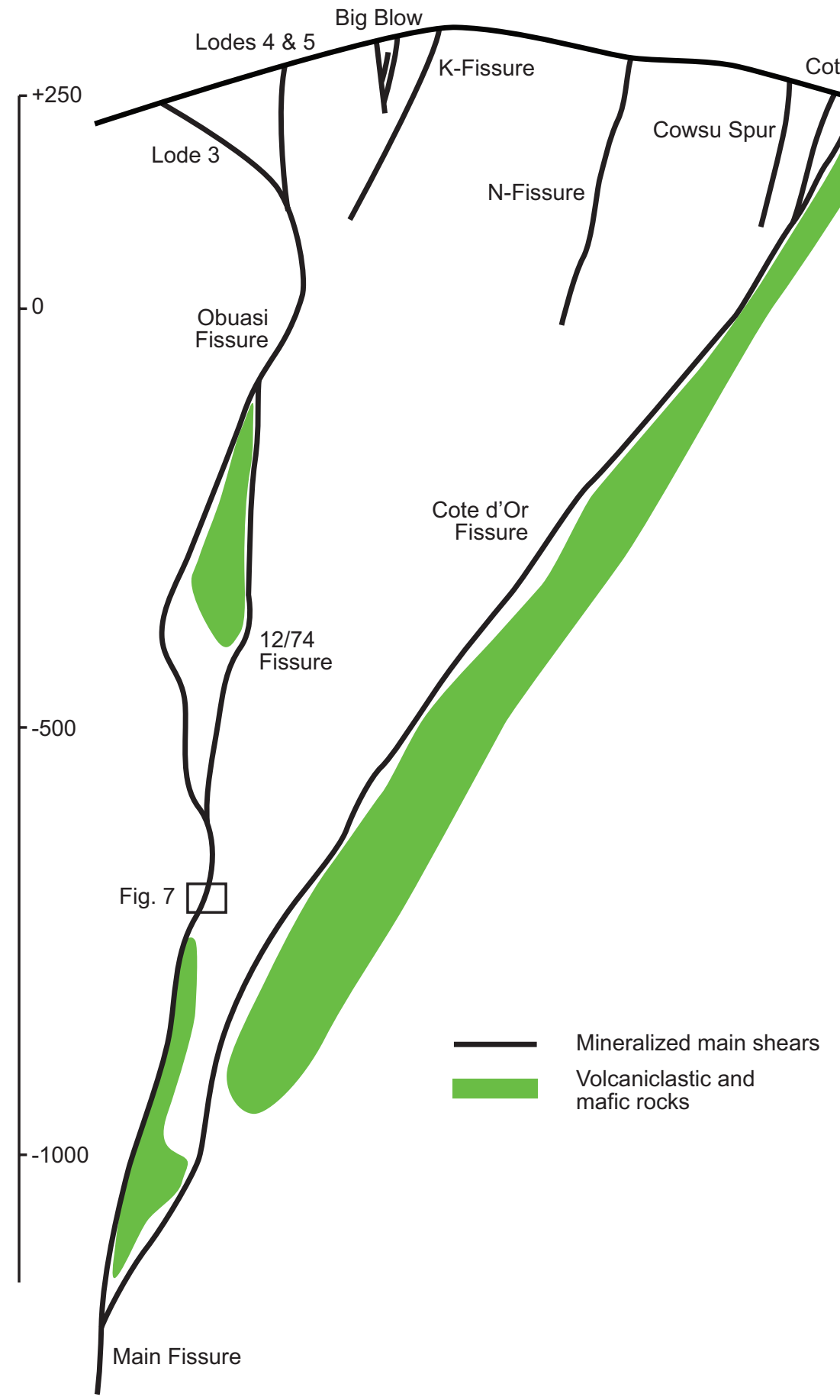

Fig. 3. Schematic cross section through KMS shaft (see Fig. 7 long section for location). Several mineralized graphiterich shear zones (called "fissures" in Obuasi mining terms) anastomose and bifurcate at depth. Lenses of volcaniclastic and mafic rocks are present influencing the geometry of the shear zones (Allibone et al., 2002).

Kunka, Yaw Mensakrom, and Nyhiaso deposits: Allibone et al., 2002). The U-Pb zircon ages for intrusions of $2105 \pm 2 \mathrm{Ma}$, as well as $\mathrm{Pb}-\mathrm{Pb}$ dates on hydrothermal rutile from the Yaw Mensakrom deposit at $2098 \pm 7 \mathrm{Ma}$, provide constraints on the mineralization age in the Binsere trend (Oberthür et al., 1998). In the Gyabunsu trend, located $2 \mathrm{~km}$ to the east of the Obuasi deposit, the host rocks are metasedimentary slates and carbonaceous phyllites, interlayered with volcaniclastic rocks. The main gold occurrences are located in the Gyabunsu, Sibi, and Zaks open pits. The mineralization in the Gyabunsu trend is mainly composed of gold-bearing sulfides, with only rare visible gold in boudinaged quartz veins and breccias. The average ore grades in deposits of the Binsere and Gyabunsu trends (5.64 Mt at $2.38 \mathrm{~g} / \mathrm{t}$ and $0.38 \mathrm{Mt} 3.92 \mathrm{~g} / \mathrm{t}$, respectively) are lower than that of the Obuasi deposit, which can average up to $21.65 \mathrm{~g} / \mathrm{t}$ in some mining blocks and has an overall resource of $159.89 \mathrm{Mt}$ at $5.32 \mathrm{~g} / \mathrm{t}$, containing a total of $27.26 \mathrm{Moz}$ of gold (AngloGold-Ashanti, 2014). Notwithstanding their lower grades, the Binsere and Gyabunsu trends still constitute an important ore resource in the district (Allibone et al., 2002). 


\section{Methods}

\section{Field observations, mapping, and sample collection}

Open-pit exposures in each trend in the district (Anyankyerim pit for the Binsere trend, Sibi pit for the Gyabunsu trend, Coral Snake-Anyinam-Big Blow and Sansu pits for the Obuasi deposit) and underground exposures at the Obuasi deposit were studied and mapped in detail. Underground exposures were selected on the basis of discussions with mine geologists, as well as from interpretation of three-dimensional Leapfrog modeling of the resource wireframe and the drill core database. Mapped areas were also influenced by safety considerations and the availability of active headings. Most active areas of the mine were studied, including the Block 1 , Block 2, Block 5, Block 8, Block 9, Block 10, the Sansu North Block, and the Upper mine (located on the Ashanti "fissure"). Both fabric form line and lithologic boundary mapping techniques were followed, using aerial photographs as base maps of the open pits and geotechnical surveys when underground. Structural orientations are reported as "dip/dip direction" for planar structures and as "plunge-trend" for linear structures. Data are plotted on lower hemisphere Schmidt projections. The number of data points is reported using the prefix " $n$ ".

On the basis of the field observation, 224 samples were collected from outcrop, underground exposure, and drill core, in order to provide a representative database of fault rocks, fabrics, alteration, and ore zones. Geotechnical drill holes were used to collect representative least altered samples distal to the mineralization.

\section{Petrography and microchemical analysis}

Strain fabric characterization, mineral identification, mineral chemistry zonation, overprinting relationships, and paragenesis were investigated with optical techniques and scanning electron microscopy (SEM). Backscattered electron images were generated using a TESCAN VEGA3 SEM. Energy dispersive X-ray spectra (EDX) were acquired using an Oxford instruments X-Max 50 silicon drift detector with AZtec software fitted on the TESCAN VEGA3. Analytical conditions were $15-\mathrm{kV}$ accelerating voltage with a 1.5 -nA probe current.

A JEOL JXA-8530F field-emission gun hyperprobe (electron probe microanalyzer (EPMA)) was used for microchemical characterization of gold-bearing arsenopyrite grains. Analyses were performed using the five wavelength dispersive spectrometers. Gold was analyzed simultaneously on two spectrometers, which were integrated to improve the detection limit. Peak count times for all elements analyzed (, $\mathrm{Fe}$, $\mathrm{As}, \mathrm{Au}$ ) were $160 \mathrm{~s}$ per element per spectrometer. Analytical conditions were $20-\mathrm{kV}$ accelerating voltage, 50 -nA probe current, and a point beam. During these analyses, we determined the detection limits to be approximately $230 \mathrm{ppm} \mathrm{Au}$ in the arsenopyrite grains.

\section{High-resolution X-ray computed tomography}

To investigate the three-dimensional distribution and geometric relationships of the native gold in the quartz veins, a 25-mm core of a high-grade quartz sample was scanned using the XRADIA Versa XRM 500 3D X-ray microscope, installed at the Australian Resource Research Centre (CSIRO, Kensington, Western Australia). The instrument was operated at $160-\mathrm{kV}$ accelerating potential and $62-\mathrm{mA}$ current and obtained a voxel size of $13.0 \mu \mathrm{m}$. A total of 2,000 projections were recorded over $360^{\circ}$ and were used to reconstruct a three-dimensional volume. The data were processed according to the method of Godel (2013).

\section{Structure, Fabrics, and Deformation History of the Obuasi District}

This section presents descriptions of the fabrics and overprinting relationships in the Obuasi district, and particularly at the Obuasi deposit, in order to describe a framework by which the timing of mineralization can be established. Multiple deformation fabrics of varying intensity and folding, as well as multiple vein generations, are present in the Obuasi district. A complex structural sequence has been recognized, and two slightly different schemes have been previously proposed (Blenkinsop et al., 1994; Allibone et al., 2002). In the following section, the subscript "Ob" is used to describe the fabrics observed in the Obuasi district during this present study, whereas the subscripts "Al" and "Bl" are used to refer to the fabrics observed by Allibone et al. (2002) and Blenkinsop et al. (1994; Table 3). We use the scheme of Passchier and Trouw (2005) to describe the fabrics. Foliations are classified as either continuous cleavage, when describing rocks with platy minerals that share the same orientation and are closely spaced, or spaced cleavage to describe rocks composed of the repetitive succession of cleavage domains and microlithons. Crenulation cleavage consists of spaced cleavage that preserves older, microfolded fabrics in its microlithons.

Early fabrics SO-S1 $\mathrm{Ob}$

The bedding $(\mathrm{S} 0)$ in the metaturbidite sequence is defined by alternating layers of dark colored, fine-grained and lightcolored, coarse-grained sedimentary rocks (Fig. 4a). Facing and younging directions were mapped and shown to change rapidly over short distances of $<10 \mathrm{~m}$, indicating tight internal folding of the lithologies. The bedding typically dips steeply northwest to southeast and the distribution of the bedding orientations plotted on a stereonet describes a weak girdle consistent with folding of the lithology (Fig. 5).

The oldest secondary foliation $\left(\mathrm{S}_{\mathrm{Ob}}\right)$ corresponds to a lowangle or bedding-parallel cleavage that is rarely preserved. The few existing measurements of $\mathrm{Sl}_{\mathrm{Ob}}$ orientation are preserved within hinges of upright tight $\mathrm{F}_{2}$ folds.

\section{Dominant fabric $S 2_{\mathrm{Ob}}$ and subhorizontal stretching}

The dominant foliation $\left(\mathrm{S} 2_{\mathrm{Ob}}\right)$ is a continuous cleavage at the micron scale defined by fine-grained, elongate muscovite and quartz grains. In the Obuasi district, $\mathrm{S}_{\mathrm{Ob}}$ strikes northeast and dips subvertically, with dip directions varying from southeast to northwest (Fig. 5). The $\mathrm{S} 2$ Ob cleavage is parallel to the fold axial planes of gently plunging tight to isoclinal folds. The $\mathrm{F} 2 \mathrm{Ob}$ folds plunge dominantly toward the northeast, but southwest plunges also occur, indicating these folds are either noncylindrical and thus doubly plunging, or underwent post-F2 $\mathrm{Ob}$ modification. The $\mathrm{S} 2_{\mathrm{Ob}}$ overprints both bedding (Fig. $4 \mathrm{a}$ ) and $\mathrm{S} 1_{\mathrm{Ob}}$, and in places $\mathrm{S} 2_{\mathrm{Ob}}$ entirely transposes the earlier fabrics. The $\mathrm{S} 2_{\mathrm{Ob}}$ cleavage is very consistent across the district.

At the district scale, an intense stretching occurred during the development of S2 $\mathrm{Ob}$ (Blenkinsop et al., 1994). Stretching 

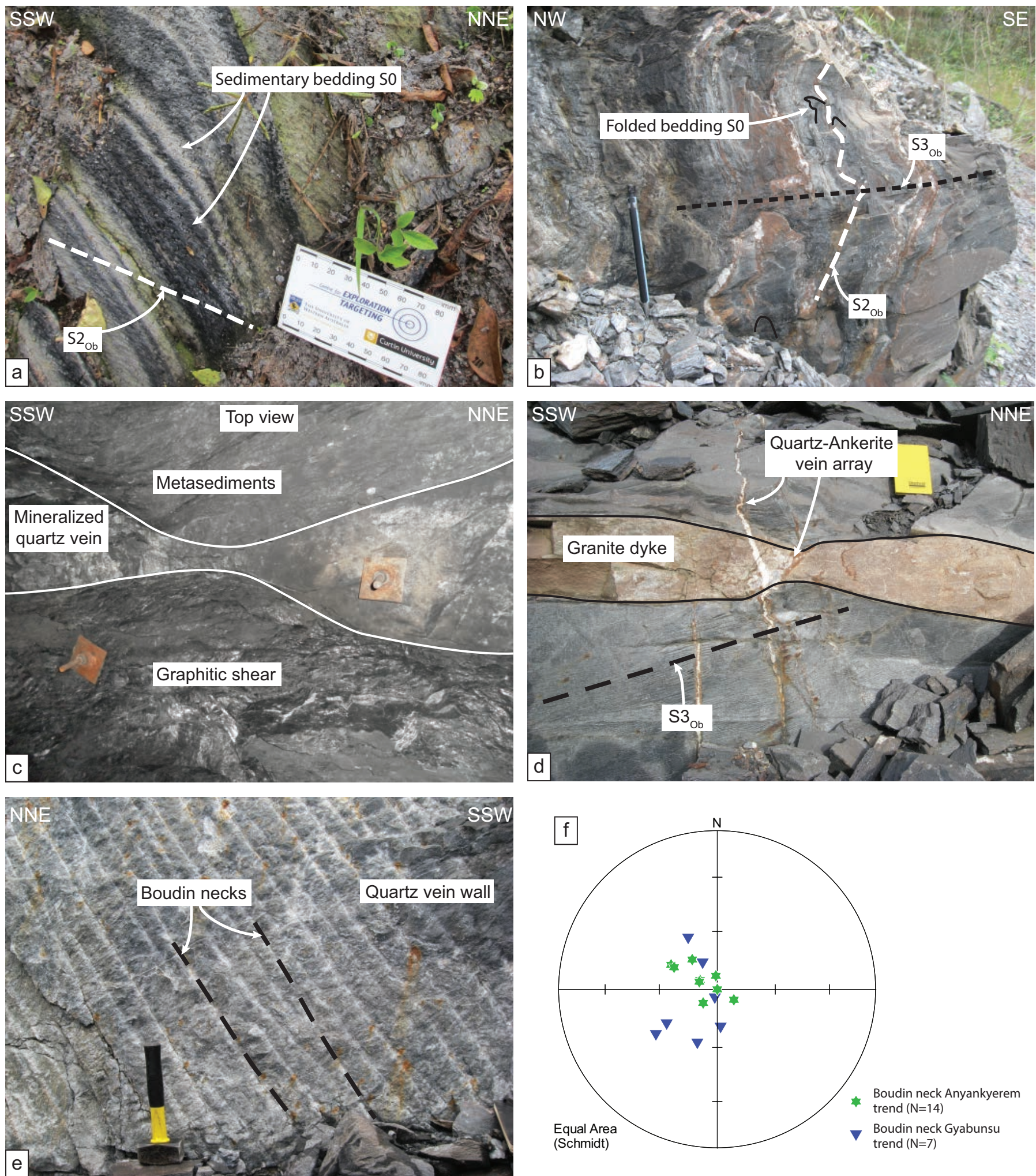

Fig. 4. a. Alternating layers of dark and light lithologies marking the bedding in metaturbidite host rocks. $\mathrm{S} 2_{\mathrm{Ob}}$ overprints $\mathrm{S} 0_{\mathrm{Ob}}$. b. $\mathrm{S} 3_{\mathrm{Ob}}$ crosscut and folds both $\mathrm{S} 2_{\mathrm{Ob}}$ and $\mathrm{S} 0_{\mathrm{Ob}}$. c. Boudinaged mineralized quartz vein adjacent to a graphitic shear, underground in the Obuasi mine (level L39\#1, crosscut 86; rock bolts for scale). d. Boudinaged and mineralized dike with subvertical quartz veins and intense quartz veining in the boudin neck area (Anyankyerem pit, Binsere trend). e. Boudinaged quartz vein in the wall of Sibi pit, Gyabunsu trend. f. Compilation of boudin neck orientations (plunge/azimuth) from quartz veins and dikes across the Obuasi district. The data show that the subhorizontal stretch direction is consistent across the district. 


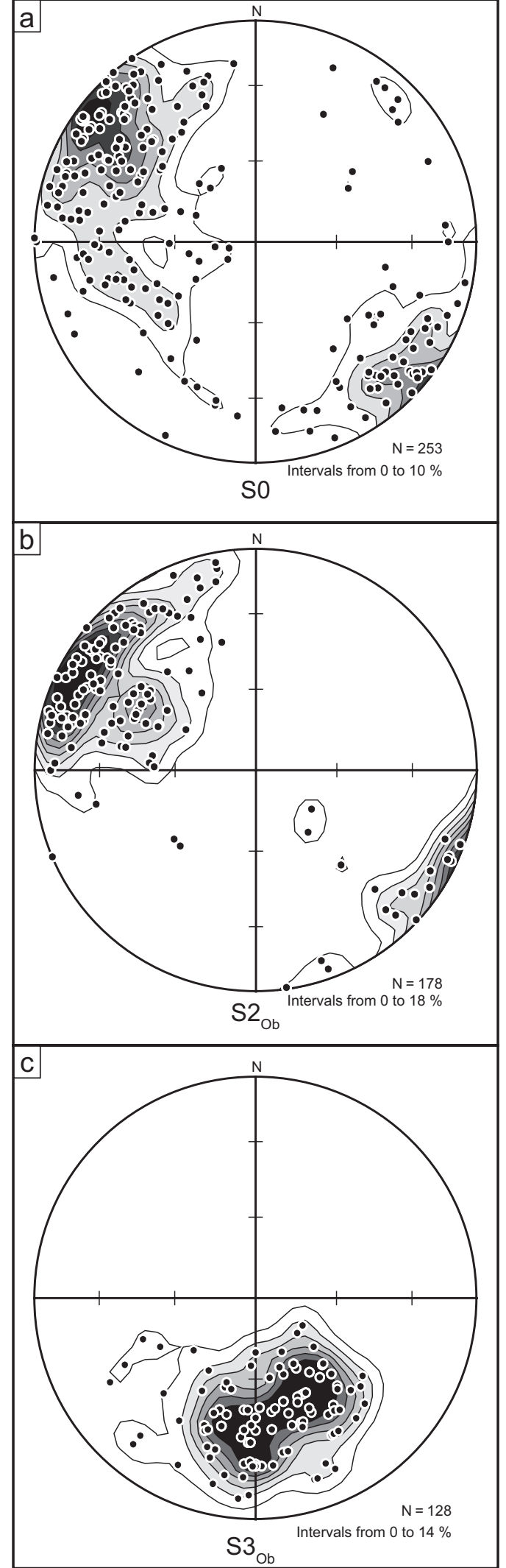

Fig. 5. Stereographic projections of poles to plane for (a) the sedimentary bedding ( $\mathrm{S} 0$ ), (b) $\mathrm{S} 2_{\mathrm{Ob}}$, and (c) $\mathrm{S} 3_{\mathrm{Ob}}$. The steep bedding is folded dominantly by $\mathrm{S} 2 \mathrm{Ob}$ around NE-plunging fold axes. Orientations of moderately dipping $\mathrm{S} 3 \mathrm{ob}$ are more tightly grouped compared to $\mathrm{S} 2 \mathrm{Ob}$ orientations. occurs across all three mineralized trends and is preserved in the form of symmetric boudinage of mineralized and unmineralized quartz veins and igneous dikes, as well as symmetric strain shadows surrounding sulfide grains (Figs. 4, 6). The plunge direction of the boudin necks is relatively consistent in the Anyankyerim (steep NE-plunging boudins) and Gyabunsu (steep SE-plunging boudins) trends (Fig. 4f). Most boudin necks are subvertical indicating a subhorizontal stretching.

In the Obuasi deposit, the stretch is recorded by both boudinaged quartz veins on the macroscopic scale and symmetric quartz strain shadows surrounding porphyroblasts on the microscopic scale. The orientation of the strain shadows surrounding porphyroblasts also indicates subhorizontal stretching, and this was checked in sections cut orthogonal and parallel to the foliation. Pinch-and-swell features and boudinage are common (Fig. 4c), and mullion structures (Blenkinsop et al., 1994; Goscombe et al., 2004; Fossen, 2010) can also be observed, although at the Obuasi deposit their significance is poorly understood. Depending on the width of the quartz vein, the spacing of the boudin necks is variable from tens of centimeters to tens of meters and no systematic wavelength could be measured. Earlier generations of porphyroblasts of carbonate and sulfide grains are associated with the development of quartz strain shadows. The axial planes of the strain shadows are parallel to the $\mathrm{S} 2_{\mathrm{Ob}}$ cleavage and are crenulated by subsequent $\mathrm{S} 3_{\mathrm{ob}}$ crenulation cleavage (Fig. $6 \mathrm{a}, \mathrm{b}, \mathrm{d}$ ). The majority of strain shadows are symmetric implying bulk pure shear. The only asymmetric strain shadows present indicate opposing movement directions relative to one another and therefore remain consistent with pure shear deformation on the thin section scale (Fig. 6c). The orientations of the strain shadows indicate subhorizontal stretching $(\lambda 1)$ parallel with the $\mathrm{S} 2 \mathrm{ob}$ cleavage.

In the Anyankyerem deposit along the Binsere trend, granite dikes and sills intruding subvertical bedding are homogeneously altered to quartz, sericite, and carbonates (Yao and Robb, 2000) and are boudinaged. The mineralization style differs from the Obuasi deposit and is expressed by dikes cut by a generation of quartz veins (Fig. 4d), containing gold-bearing sulfides and rare visible gold. These veins are subvertical, striking W-E to NW-SE, intensely developed in the subvertical boudin neck regions of the sills and dikes but folded by later fabric. The mineralized veins are therefore interpreted to have formed during boudinage. Boudinage of the quartz vein arrays in the Obuasi deposit and the granite dikes in Anyankyerem is consistent with a subhorizontal stretching direction $(\lambda 1)$ trending NNE-SSW, which is parallel to the $\mathrm{S} 2 \mathrm{Ob}$ cleavage.

Finally, a critical observation is that the majority of shear zones and faults across the Obuasi district share the same orientation as $\mathrm{S} 2 \mathrm{Ob}$. They are subparallel to the margin of the volcanic belts and sedimentary basins (Fig. 1).

\section{Late crenulation fabric $\mathrm{S} 3 \mathrm{Ob}$}

A late spaced foliation $(\mathrm{S} 3 \mathrm{Ob})$ overprints the earlier fabrics and defines a crenulation cleavage (Passchier and Trouw, 2005). The cleavage domains are defined by concentrations of graphite particles, whereas the microlithons preserve the primary rock mineralogy (i.e., muscovite, quartz, and carbonates) and older $\mathrm{S} 2_{\mathrm{Ob}}$ and $\mathrm{S} 0$ foliations. The cleavage domains are smooth, 

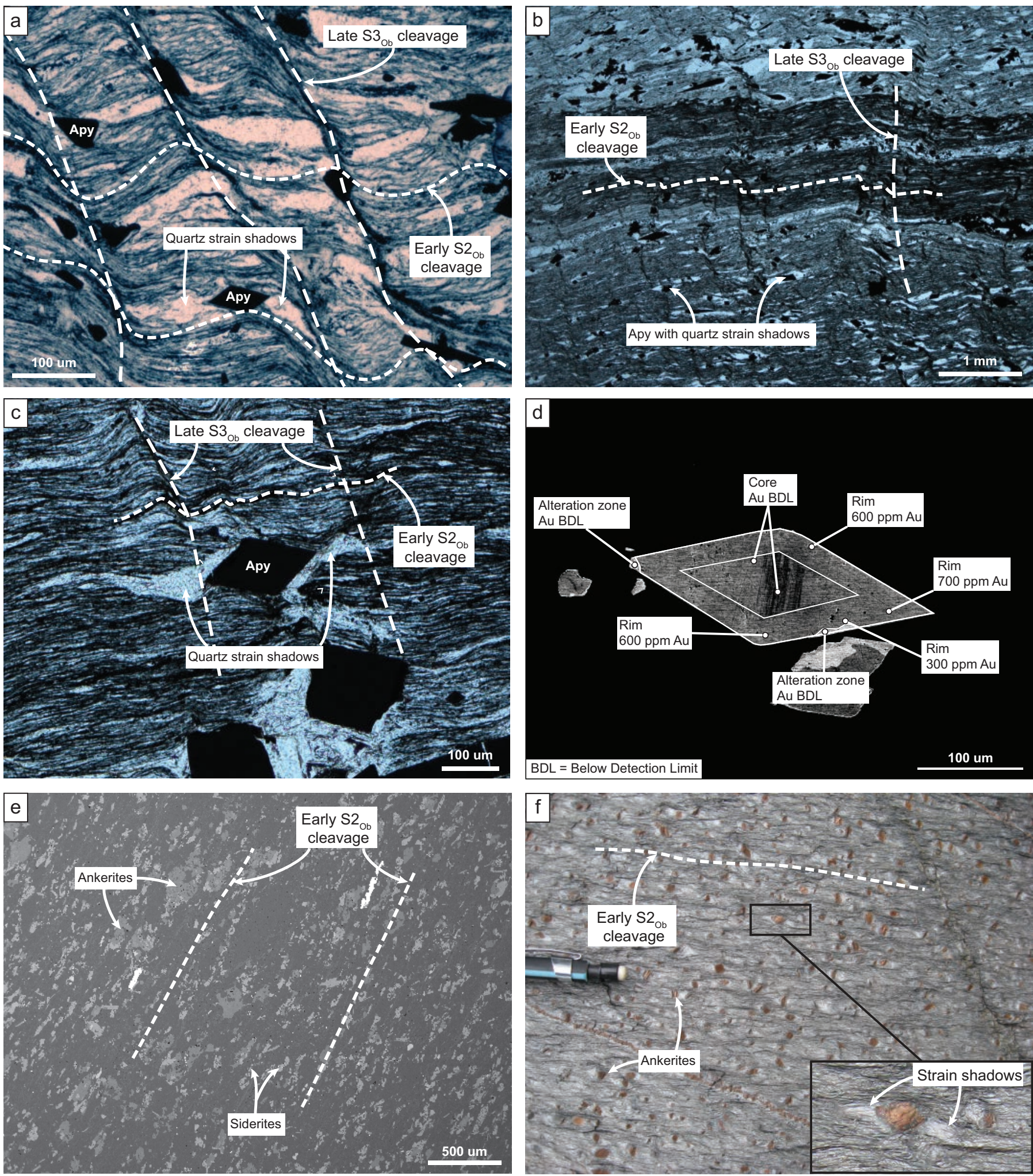

Fig. 6. a, b. and c. Optical micrograph of gold-bearing arsenopyrites in sedimentary rocks (phyllites). Most of the arsenopyrites have strain shadows aligned with the main pervasive cleavage and refolded by the later spaced cleavage. Their strain caps, developed by the accumulation of cleavage planes against a hard object, are only weakly developed. d. Backscattered image of an arsenopyrite; EPMA gold concentrations are reported up to $700 \mathrm{ppm}$. BDL refers to "below detection limit" (Table 1; sample DF073(1)). e. Backscattered image of siderites and ankerite aligned with the NE-SW cleavage. f. Photograph of ankerite aligned with the NE-SW cleavage. Inset shows strain shadows around the ankerite grains parallel to $\mathrm{S} 2_{\mathrm{Ob}}$ and refolded by S3ob. 
representing a volume of 1 to $5 \%$ and a spacing of approximately 100 to $200 \mu \mathrm{m}$. The cleavage is parallel and the transition between cleavage domains and microlithons is discrete.

The $\mathrm{S}_{\mathrm{Ob}}$ cleavage has the same orientation as the axial plane of $\mathrm{F} 3_{\mathrm{Ob}}$ folds and cuts across all previous fabrics (Figs. $4 \mathrm{~b}, 6$ ). The $\mathrm{F} 33_{\mathrm{Ob}}$ folds are asymmetric and they plunge $20^{\circ}$ to $50^{\circ}$ to the northeast, whereas the orientation of $\mathrm{S} 3 \mathrm{Ob}$ varies across the Obuasi district (striking ENE-WSW to E-W and dipping $20^{\circ}-60^{\circ}$; Fig. 5). The S3ob cleavage shows spatially, as well as lithologically controlled strain partitioning, thus leaving some domains and lithologies undeformed (Blenkinsop et al., 1994; Allibone et al., 2002). The S3ob is better developed in fine-grained phyllites and does not appear to be present in the graywackes and volcaniclastic rocks. A common intersection lineation is developed between $\mathrm{S} 2_{\mathrm{Ob}}$ and $\mathrm{S} 3_{\mathrm{Ob}}$ and proved to be a useful identifier of the later cleavage. In contrast to $\mathrm{S} 2 \mathrm{Ob}$, no major faults share the same orientation with $\mathrm{S} 3 \mathrm{ob}$.

\section{Quartz vein populations}

Various quartz vein generations and orientations are present across the Obuasi district and within the Obuasi deposit. There are quartz ( \pm carbonates) vein populations parallel with S0, S2 $\mathrm{Ob}$, and S3 $\mathrm{Ob}$. Less commonly, subvertical veins perpendicular to $\mathrm{S} 2 \mathrm{Ob}$, and subhorizontal folded veins can be observed in the Obuasi and Anyankyerem deposits. These veins range in thickness from millimeters to a few tens of centimeters and it has been reported that all orientations are mineralized to some extent (Blenkinsop et al., 1994). Late barren quartz veins with various textures and orientations, from en echelon steep to flat-lying veins, crosscut all structures.

In this study, we focus on a population of thick quartz veins closely associated with graphite-rich shears at the boundaries of the ore zone. These veins, or quartz lodes, are restricted to the Obuasi deposit, attaining widths of as much as $25 \mathrm{~m}$ when two or more graphitic shears intersect. Commonly, the quartz veins strike NE-SW, and thus parallel with $\mathrm{S}_{\mathrm{Ob}}$, dip to the west, and are spatially associated with the margins of graphite-rich shear zones. They are deformed into a pinchand-swell morphology (Blenkinsop et al., 1994), with subvertical and less commonly subhorizontal boudin necks (Fig. 4c, f). These veins contain variable amounts of visible gold, which contribute to local high gold grades, with $>1,500 \mathrm{~g} / \mathrm{t}$ Au across individual channel samples. The quartz textures can be glassy, milky, or smoky; however, only the latter two categories host economic gold grades. The veins internally show crack-andseal textures, with several subparallel laminations of graphite-rich seams. Microstructurally, in the veins, the quartz is entirely recrystallized probably due to subgrain rotation and recrystallization during crystal-plastic deformation (Passchier and Trouw, 2005). Allibone et al. (2002) reported arrays of mineralized sinistral shear veins genetically linked to the thick mineralized quartz veins; however, this vein generation was not observed in the currently available exposures throughout the Obuasi mine.

\section{Summary}

The complexity of the fabric generations in the Obuasi district, and even solely within the Obuasi deposit, has led to the development of two slightly different structural models (Blenkinsop et al., 1994; Allibone et al., 2002). The new field data and the reassessment of previous data presented here indicate the structures and foliations observed at Obuasi can be depicted in a three-stage sequence.

The sedimentary bedding ( $\mathrm{S} 0$ ) is typically very distinct, with alternating layers of darker, fine-grained metapelite and lighter, commonly coarser grained metasandstone. It represents the primary foliation in the district, with younging directions commonly preserved. The oldest secondary foliation $\left(\mathrm{S} 1_{\mathrm{Ob}}\right)$ recorded in the sedimentary rocks is not well preserved. It has an acute angle with respect to the bedding (S0). The $\mathrm{S} 1_{\mathrm{Ob}}$ is folded and transposed by later structures and fabrics (Allibone et al., 2002).

The dominant secondary foliation in the Obuasi district $(\mathrm{S} 2 \mathrm{Ob})$, striking $\mathrm{NE}$ and dipping steeply $\mathrm{SE}$ to $\mathrm{NW}$, overprints the previously formed $\left(\mathrm{S} 1_{\mathrm{Ob}}\right)$. The anisotropy introduced by this cleavage possibly influences the geometry of major faults and shear zones in the district, which share the same orientation. The $\mathrm{S} 2_{\mathrm{Ob}}$ cleavage is axial planar to and formed coevally with $\mathrm{F}_{2}$ ob folds. Subhorizontal stretching occurred during the development of this cleavage, with boudinage of quartz veins and granitic dikes and the formation of quartz pressure shadows surrounding earlier generations of carbonate and sulfide porphyroblasts. Peak metamorphic conditions, calculated after the mineral assemblage of actinolite + chlorite + clinozoisite + quartz + calcite, are estimated to have been $400^{\circ}$ $\pm 50^{\circ} \mathrm{C}$ and $2 \mathrm{kbars}$ during the development of this cleavage (Schwartz et al., 1992). This main $\mathrm{S}_{\mathrm{Ob}}$ cleavage is interpreted to be the result of a NW-SE-directed shortening $(\mathrm{D} 2 \mathrm{Ob})$. The mineralized thick quartz veins are boudinaged and parallel with $\mathrm{S} 2_{\mathrm{Ob}}$, therefore they must have formed pre- to syn-D2 $2_{\mathrm{Ob}}$. This event corresponds to a period where strain was accommodated by pervasive flattening and stretch, and localized high strain along shear zones.

These fabrics are overprinted by a crenulation cleavage $(\mathrm{S} 3 \mathrm{Ob})$, the intensity of which varies across the Obuasi deposit. This spaced crenulation cleavage has a shallow dip to the NNW and formed coevally with a second generation of folding $(\mathrm{F} 3 \mathrm{Ob})$ plunging $20^{\circ}$ to $50^{\circ}$ to the NE. The far-field D3ob shortening direction is NNW-SSE to N-S and is similar to $\mathrm{D} 4_{\mathrm{Al}}$ and $\mathrm{D} 2_{\mathrm{Bl}}$ events.

The significance of this structural sequence and how it corresponds with the sequences defined by Blenkinsop et al (1994) and Allibone et al. (2002) is addressed in the later discussion section.

\section{Mineralization Styles and Relative Timing of Gold Deposition at the Obuasi Deposit}

Exposures within the Obuasi deposit comprise 20 individual ore shoots, distributed along $8 \mathrm{~km}$ of strike length and extending for at least $1.6 \mathrm{~km}$ below the surface (Fig. 7). More than 15 satellite deposits are located within parallel trends west and east of the main Obuasi deposit (Fig. 1). The ore shoots in the Obuasi deposit contain economic-grade mineralization in two distinct styles: (1) sulfides, predominantly arsenopyrite, with microscopic crystal growth zones containing high gold concentrations, and (2) quartz veins with native gold and sulfides.

In this section, we present a description of the overall geometry of the two mineralization styles before examining the geology, mineralogy, texture, and timing of each style relative to the structural sequence. 


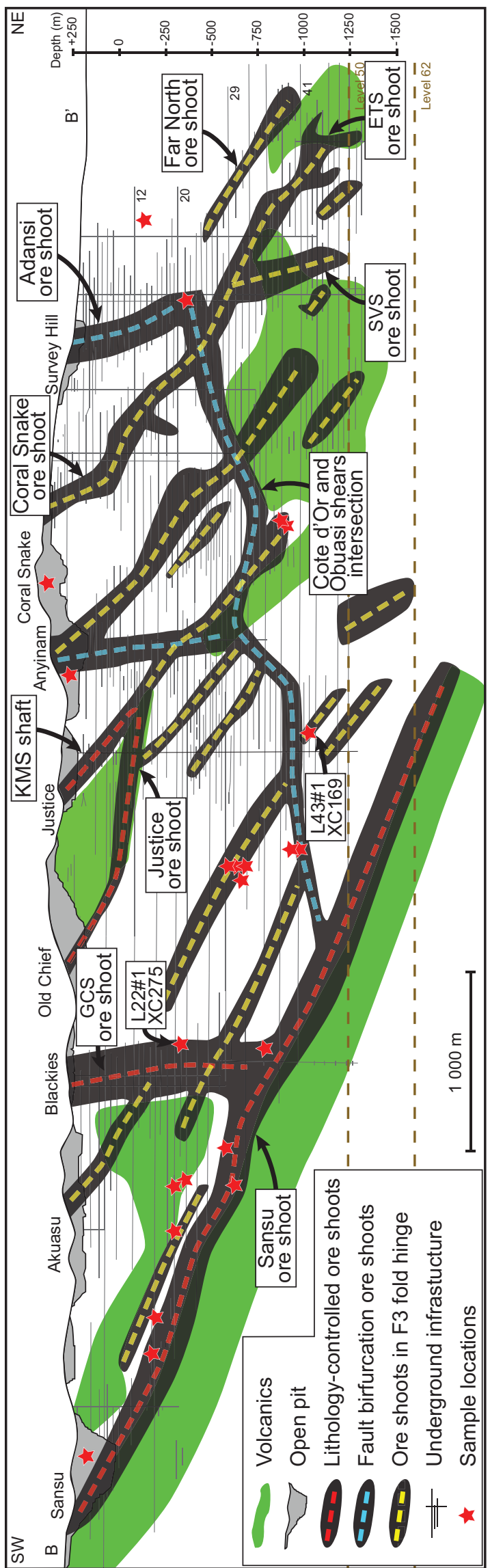

\section{Deposit-scale geometry}

A long section projection of ore shoot geometries along the main trend of the deposit is presented in Figure 7. Both mineralization styles are associated with three distinct groups of ore shoots, distinguished on the basis of geometry. These include volcanic rock and dike controlled shoots, shoots associated with fault intersections and bifurcations, and, the most dominant ore shoot group that is associated with F3ob fold hinges. These geometries were previously identified by Allibone et al. (2002).

The first group of ore shoots correlate with the location of the metavolcanic rocks (Fig. 7). The competency contrast between the hard volcanic units and the more ductile phyllite units is inferred to control the location of the mineralization. The distribution of these units is also interpreted to have had a control on fault propagation through the sequence, as faults commonly form on rheological boundaries. The geometry of the volcanic rocks and dikes reflects the primary intrusive or extrusive geometry and the subsequent deformation overprinting these units. The most remarkable example of this type of ore shoot is the Sansu orebody, associated with the Sansu dike, which cuts through the bedding and is interpreted to form pre- to syn-Dlob (Allibone et al., 2002). The orebody crops out at the surface in the Sansu pit. Exploration below the 50 level at a depth of more than 1,500 m has not yet reached the base of this mineralization. In the central part of the Obuasi deposit, the Justice ore shoot is also controlled by a volcanic body.

The second group of ore shoots is subhorizontal, plunging steeply to the northeast or shallowly to the south. Our threedimensional modeling combined with field mapping has identified that these shoots correspond to anastomosing fault splays, and areas where fault tip bifurcation lines enhance permeability and fluid circulation (e.g., Walsh et al., 1999). Allibone et al. (2002) recognized the same control on these ore shoots. Examples of these ore shoots are the Adansi and Anyinam orebodies (Fig. 7). The largest ore shoot of this type is where the Ashanti and Obuasi shear zones merge.

The third group, which is most dominant group of ore shoots, plunges moderately to the northeast at $20^{\circ}$ to $40^{\circ}$. The shoots are consistent with $\mathrm{F}_{3} \mathrm{ob}$ fold hinges of the graphiterich shear zones or the intersection line between the graphite-rich shear zones and the $\mathrm{S} 3 \mathrm{ob}$ cleavage (Blenkinsop et al., 1994; Allibone et al., 2002; Fougerouse et al., 2013). Although $\mathrm{F} 2 \mathrm{Ob}$ and $\mathrm{F} 3 \mathrm{Ob}$ both plunge to the northeast, it was possible to discriminate between fold generations using axial plane overprint relationships and confirm that the ore shoots follow the F 3 ob fold hinges. Examples of this type of ore shoot include Coral Snake, ETS, Far North, and SVS (Fig. 7).

\section{Ore zone-scale geometry}

The ore zones commonly dip steeply to the NW, comprising one or several thick mineralized quartz veins and sulfide-rich ores disseminated between two graphitic shears (Fig. 8). The sulfide ores have increased in their relative economic importance during the past few decades. Their mineralogy is dominated by arsenopyrite, comprising 60 to $95 \%$ of the sulfides, but also with pyrite, pyrrhotite, marcasite, and chalcopyrite, with gold present in the crystal lattice of the sulfides and more 


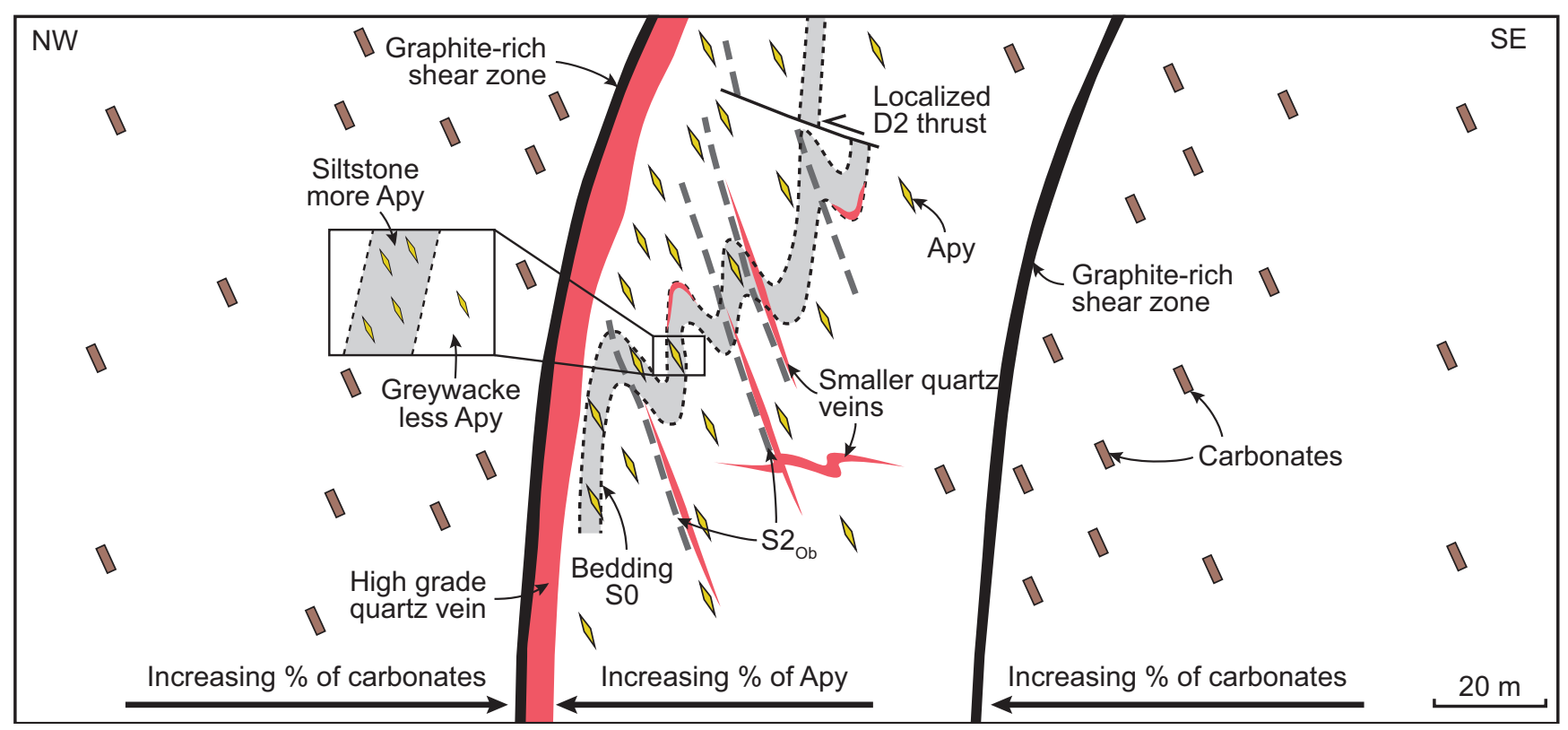

Fig. 8. Schematic cross section through a typical ore zone. The ore zone is often constrained between two graphitic faults with a thick quartz vein typically located on the western side of the ore zone. The proportion of gold-bearing arsenopyrite increases toward the mineralized quartz veins, whereas the proportion of carbonates increases toward the ore zone.

rarely as native gold in microcracks in the sulfides (Oberthür et al., 1994).

The thick, mineralized quartz veins sometimes have exceptional gold grades that locally can reach a few percent. Several graphite-rich shear zones and associated thick quartz veins may be present in the same ore zone (Fig. 3) and commonly are given the names West, Central, or Hanging wall lodes. The veins consist of quartz, minor ankerite, sulfides $(<1 \%)$, and host-rock fragments.

\section{Mineralization style I: Arsenopyrite-hosted gold mineralization and its relationship to deformation fabrics}

The sulfide ores, herein referred to as mineralization style I, represent the refractory ores of the Obuasi mining operations. In this section, we document the mineralogy, chemistry, and microstructures of this mineralization style.

The distribution of arsenopyrite decreases away from the thick quartz veins and thus defines an arsenopyrite halo surrounding the veins. In the ore zones, the abundance of arsenopyrite is typically higher in the fine-grained psammite than in the graywacke (Fig. 8).

The SEM images and EPMA analyses revealed zoning of the larger arsenopyrite grains with multiple zones of goldenriched rims and typically gold-poor cores (Fig. 6d). Gold concentration in the rims can reach as high as $700 \mathrm{ppm}$, whereas concentrations in the cores are below the detection limit of $230 \mathrm{ppm}$ (Table 1). This observation confirms SIMS (secondary ion mass spectrometer) analyses and interpretations from previous studies (Oberthür et al., 1994, 1997). No micronuggets or gold particles were observed at the micron scale in the arsenopyrite grains, except rarely in crosscutting microcracks, so almost all gold must be present in solid solution or as nanoparticles. Along grain boundaries, there are small, spatially restricted zones in the arsenopyrite grains characterized by brighter backscatter in SEM photomicrographs, indicating a higher than average atomic mass (Fig. 6d; Morey et al., 2008). In these zones, gold concentrations are below detection limit, whereas arsenic concentrations are higher and sulfur content lower relative to the remainder of the arsenopyrite rims. Following the description of Morey et al. (2008), these zones are considered to be the result of alteration and chemical modification.

Petrography and microstructural studies show that a large proportion (80-90\%) of the gold-bearing arsenopyrite grains disseminated in the sedimentary rocks are aligned with $\mathrm{S} 2_{\mathrm{Ob}}$. Approximately $50 \%$ of these gold-bearing sulfides are associated with quartz strain shadows also parallel with $\mathrm{S} 2_{\mathrm{Ob}}$, which are reworked and crenulated by the $\mathrm{S} 3 \mathrm{Ob}$ crenulation cleavage (Fig. 6a, b, d). Typically, arsenopyrite grains have only have weak strain caps on their margins orthogonal to the strain shadows, consistent with crystallization occurring synchronous with $\mathrm{D} 2_{\mathrm{Ob}}$ (Passchier and Trouw, 2005). The strain shadow orientation is concordant with the $\mathrm{D} 2 \mathrm{Ob}_{\mathrm{Ob}}$ subhorizontal stretching. It is important to note that some samples

Table 1. Microprobe Analysis of Sample DF073(1) (in wt \%)

\begin{tabular}{lccccr}
\hline \hline & S & As & Au & Fe & Total \\
\hline Core & 23.309 & 41.894 & BDL & 35.859 & 101.06 \\
Core & 21.995 & 43.740 & BDL & 35.190 & 100.92 \\
Rim & 22.047 & 43.860 & 0.06 & 35.063 & 101.03 \\
Rim & 22.319 & 43.901 & 0.07 & 35.380 & 101.67 \\
Rim & 21.558 & 44.718 & 0.03 & 34.979 & 101.28 \\
Rim & 21.524 & 44.320 & 0.06 & 34.831 & 100.74 \\
Alteration zone & 20.072 & 45.444 & BDL & 33.580 & 99.10 \\
Alteration zone & 20.752 & 46.059 & BDL & 34.730 & 101.54 \\
& & & & & \\
\hline
\end{tabular}

Note: $\mathrm{BDL}=$ below detection limit $(230 \mathrm{ppm})$ 
do not show strain shadows surrounding sulfides and only weakly developed fabrics. A number of these samples are grains hosted by the coarser grained sedimentary rocks, reflecting a lithologic control rather than a difference in timing. Notwithstanding this, Allibone et al. (2002) reported large needles of arsenopyrite overprinting the latest cleavage $(\mathrm{S} 3 \mathrm{Ob})$, indicating formation during a later event. However, the scarcity of these larger arsenopyrite grains suggests that later events were associated with only limited amounts of disseminated sulfide and related gold deposition. The width of the arsenopyrite halo can reach up to $50 \mathrm{~m}$ from the thick quartz veins.

In addition to the mineralized arsenopyrite, the metasedimentary rocks preserve a 25 - to 50 -m-wide ankerite and siderite alteration halo from the edges of the arsenopyrite mineralization. Petrography, integrated with field work and systematic sampling demonstrates that the alteration is zoned with an inner halo of arsenopyrite surrounding the quartz veins and an outer halo of carbonates. Both of the carbonate minerals are deformed within the $\mathrm{S} 2 \mathrm{Ob}$ cleavage and host inclusions of quartz and mica, parallel with the $\mathrm{S} 2 \mathrm{Ob}$ cleavage, indicating precipitation contemporaneous with development of this cleavage (Fig. 6e, f; cf. Passchier and Trouw, 2005).
Mineralization style II: Visible gold and its relationship to late-stage fracturing and folding

The quartz vein-hosted ores, herein termed mineralization style II, are extremely high grade and characterized by visible gold. In this section, we describe the nature of this mineralization style using observations from underground mapping, SEM data, and X-ray computed tomography.

More than 20 localities were mapped underground in the Obuasi deposit. Two exceptionally high grade examples are presented in more detail here, from level 22 crosscut 275 and level 43 crosscut 169. The sublevel 22 crosscut 275 (L22\#1 XC275) shows a high-grade ore zone aligned with the Sansu ore shoot, plunging $20^{\circ}$ to the northeast. The meter-wide central quartz vein follows a lithologic contact between phyllites and fine-grained graywackes. The vein changes in strike by $20^{\circ}$ (Figs. 7, 9) and has extremely high grades at the bend of the vein $(3 \mathrm{~m}$ at $1,750 \mathrm{~g} / \mathrm{t} \mathrm{Au})$. A calculated $\pi$-axis, corresponding to the fold axis of the folded quartz vein (Fig. 11c), plunges at $17^{\circ}$ to the northeast. This orientation is parallel to the orientation of the late $\mathrm{F} 3 \mathrm{Ob}$ folds in the southern part of the deposit developed during $\mathrm{D} 3_{\mathrm{Ob}}$. A second, 5-m-wide quartz vein borders the graphitic shear on the western end of

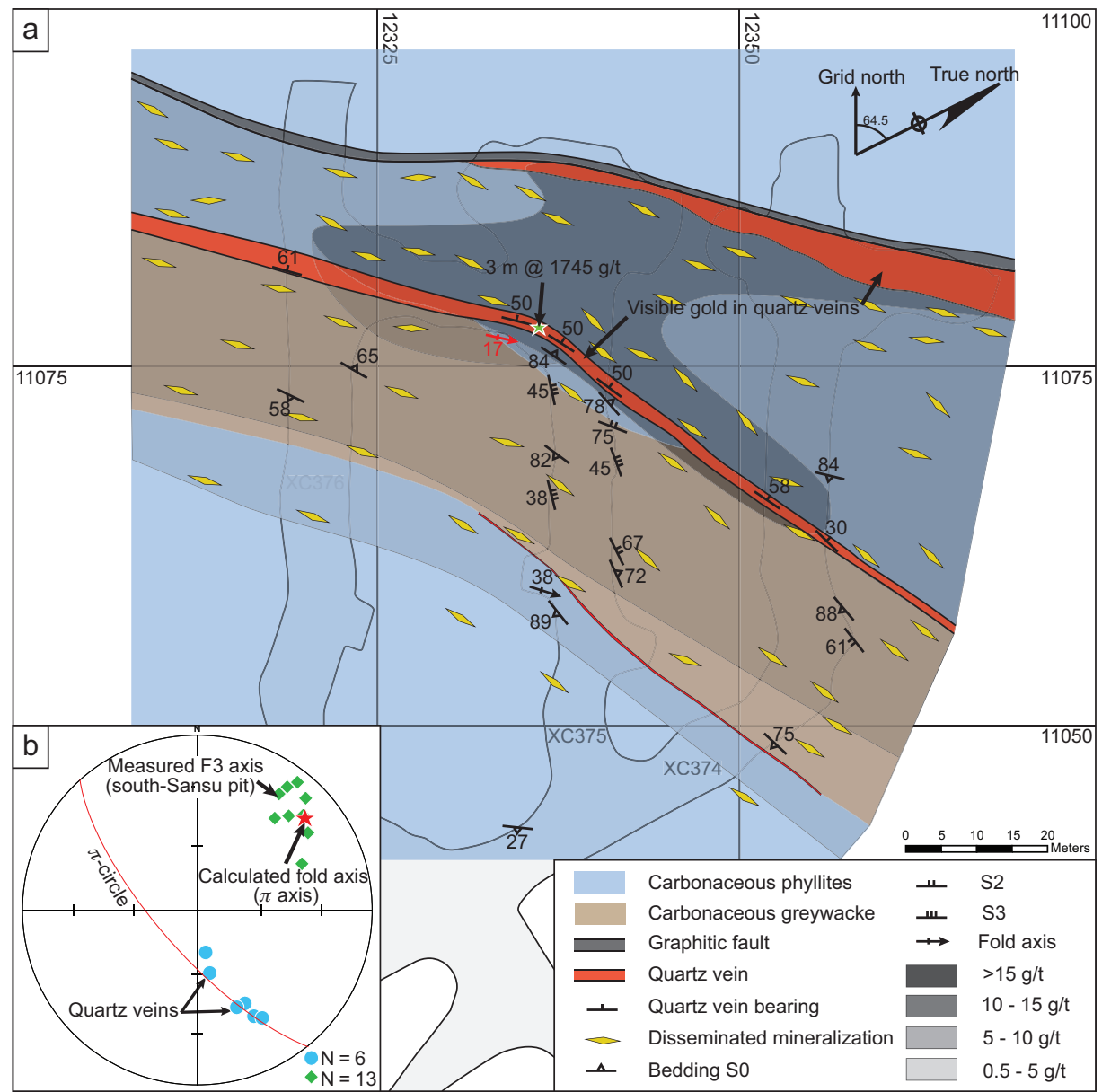

Fig. 9. Underground geologic map of level $22 \# 1$ crosscut 275 , showing grade distribution. a. The highest gold grades are located in the hinges of the late F3 folds. b. Stereonet shows the mineralized quartz vein is folded with a calculated fold axis $(\pi$-axis) corresponding to $\mathrm{F} 3 \mathrm{Ob}$ observed in the south part of the mine. 
the mineralized area with high gold grades, but contains lower grades than the vein in the central zone. In contrast to the very variable distribution of the visible gold mineralization, the gold-bearing arsenopyrite disseminated in the sedimentary rocks is evenly distributed along strike and the arsenopyrite abundance shows no spatial correlation with the folding of the quartz vein. This suggests arsenopyrite precipitation is a distinct event relative to visible gold formation.

Similar observations can be made in other areas of the mine. The sublevel 43 crosscut 169 (L43\#1 XC169) was mapped in detail to describe exposures associated with a high-grade quartz vein (Figs. 7,10 ). The quartz vein is folded with its measured fold axis parallel to the late $\mathrm{F} 3 \mathrm{ob}$ folds determined in the north part of the mine in the Anyinam pit. The graphitic faults, bedding, the zone of mineralized arsenopyrite ore (mineralization style I), and the zone of carbonate alteration are folded with the quartz vein. Furthermore, the $\mathrm{S} 3 \mathrm{Ob}$ cleavage can be measured in the metasedimentary rocks and its orientation is parallel with the axial plane of the folded quartz vein. Late gold-bearing fractures, parallel to $\mathrm{S} 3 \mathrm{ob}$, also overprint the boudinaged quartz vein, suggesting that the fractures and $\mathrm{S} 3 \mathrm{ob}$ are coeval. The grade control data (Roger Kumi pers. comm.) show that the gold concentrations in the quartz vein increase progressively toward the fold hinge of the quartz vein (Fig. 10).

The SEM and high-resolution X-ray computed tomography analyses indicate that the gold and accessory minerals are distributed along fracture planes crosscutting the quartz vein, rather than disseminated throughout the quartz vein (Figs. 11,
12). The gold particles are flaky with irregular sizes filling the porosity in the quartz created by the fracturing. In the fractures of the quartz veins, native gold is associated with muscovite and small amounts of graphite $(<1 \%)$, but also galena, chalcopyrite, sphalerite, bournonite, boulangerite, tetrahedrite, aurostibine, löellingite, pyrite, arsenopyrite, and rare bismuth tellurides as accessory minerals (Fig. 11b; Oberthür et al., 1994). The minerals are typically xenomorphic, unfractured, and can reach several hundred microns in maximum dimension. The mutual intergrowth of these minerals and gold indicates synchronous deposition (Fig. 11b; Oberthür et al., 1994). This generation of arsenopyrites, associated with native gold in the fractures of the quartz veins, can contain between 0.80 and $2.25 \%$ of gold (Oberthür et al., 1994).

Finally, at the thin-section scale, porphyroblasts of retrograde chlorite grains overprint both the $S 2_{\mathrm{Ob}}$ and late $\mathrm{S} 33_{\mathrm{ob}}$ cleavage in the metasedimentary rocks within meters of the mineralized quartz veins (Fig. 11d). The porphyroblasts form large aggregates $(>100 \mu \mathrm{m})$ and they host inclusions preserving the crenulated fabric observed in the surrounding matrix. The abundance of the overprinting chlorite increases closer to the high-grade ore zones in the quartz veins.

\section{Discussion}

\section{Model for structural evolution and multiple episodes of mineralization at Obuasi}

We have established, with respect to the relative timing of mineralization and structural evolution of the Obuasi deposit

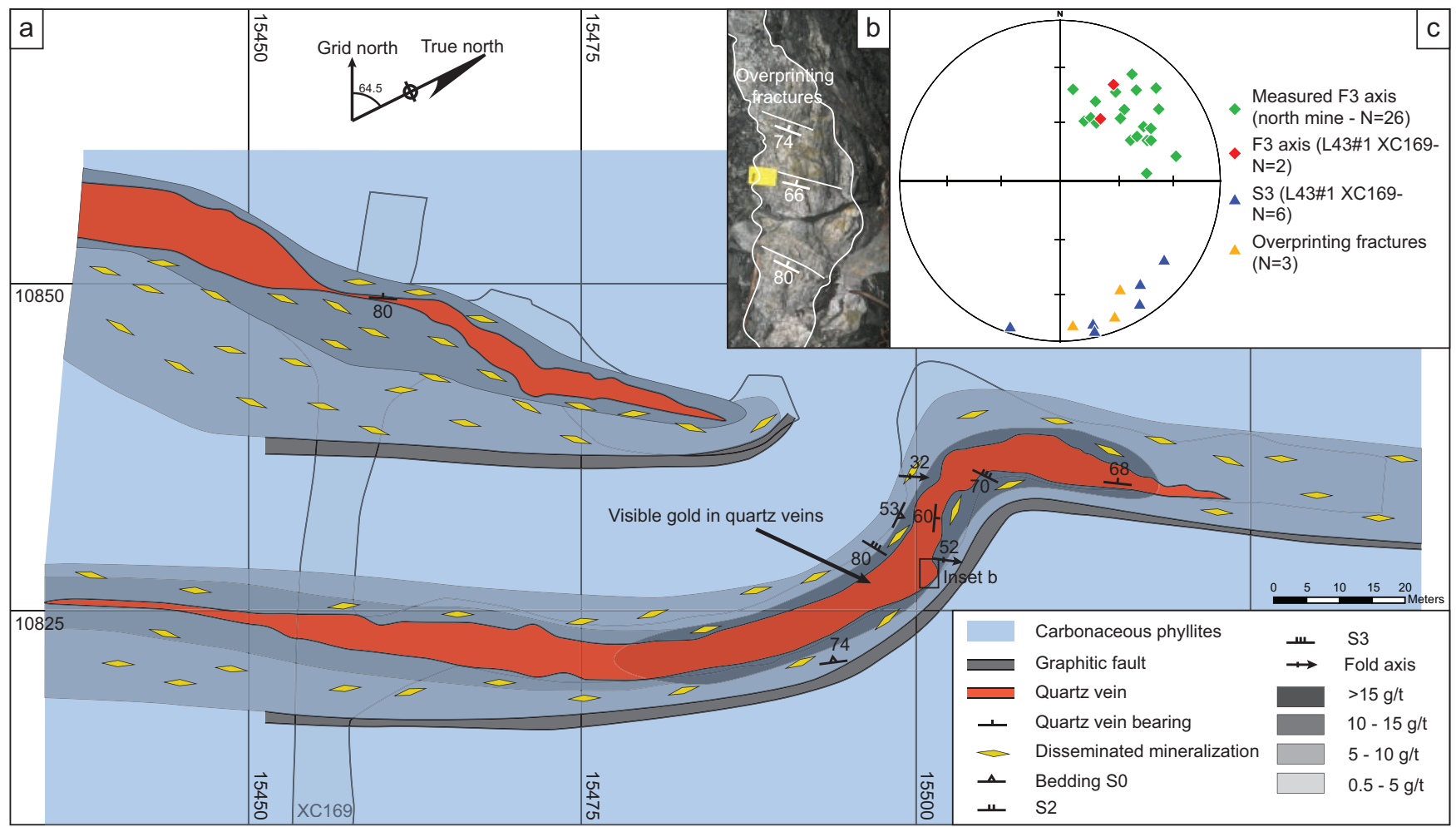

Fig. 10. Underground geologic map of level $43 \# 1$ crosscut 169. Aa. The highest gold grades are located in the hinges of the late F3 folds. b. The mineralized quartz vein is boudinaged and overprinted by late fractures parallel to the late S $33_{\mathrm{Ob}} \mathrm{E}-\mathrm{W}$ cleavage. c. Stereonets of structural measurements, the mineralized quartz vein is folded with fold axes corresponding to F3 in the north part of the mine. 

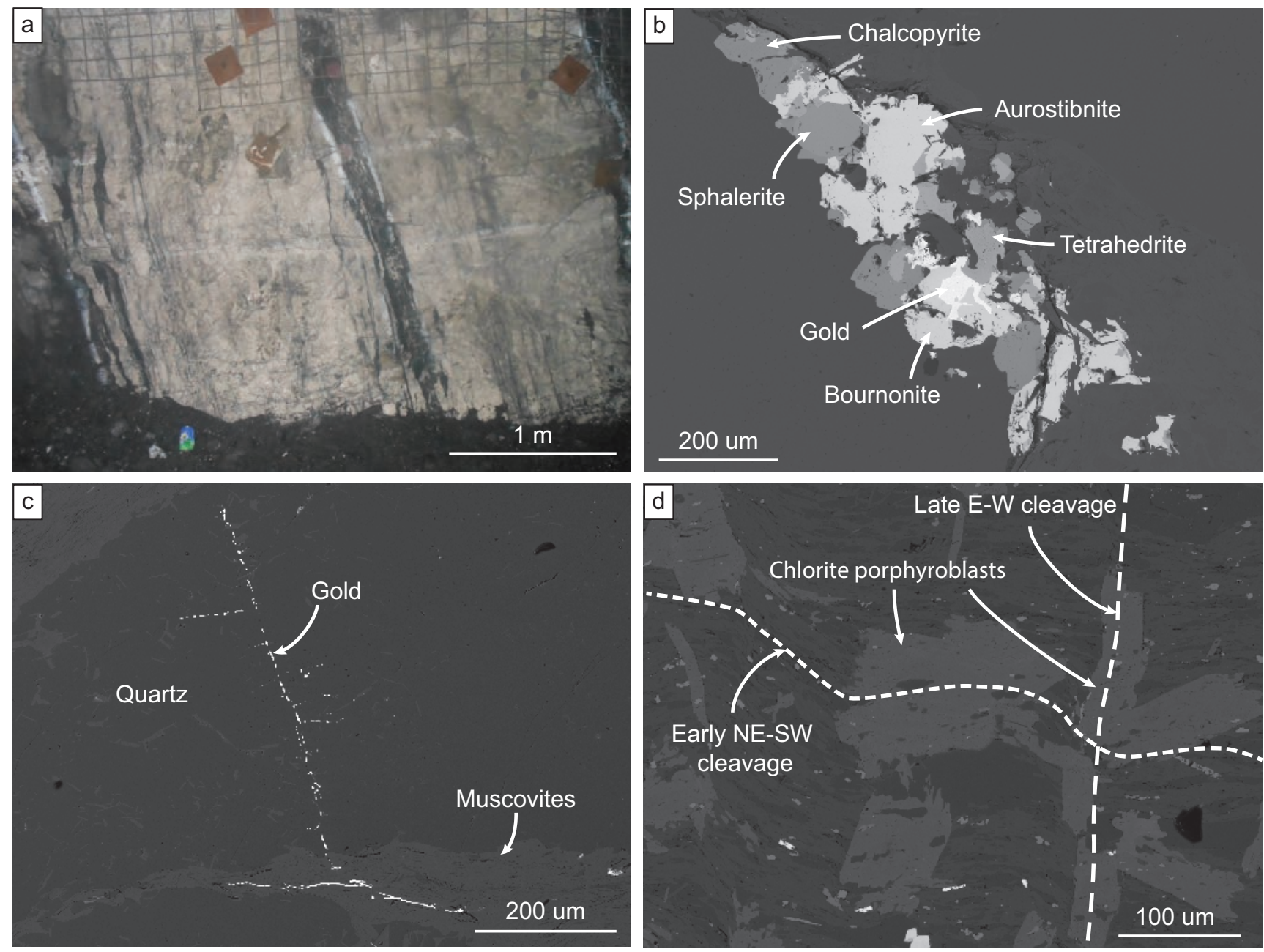

Fig. 11. a. Underground exposure of a mineralized $\sim 3$-m-wide quartz vein. b. Example of sulfides associated with the visible gold. c. Backscattered image of gold confined to a fracture network in a quartz vein and concentrated along a microfracture developed within muscovite aggregates, parallel to muscovite cleavage. d. Chlorite porphyroblasts overprinting the late $\mathrm{S} 3_{\mathrm{Ob}}$ E-W cleavage.
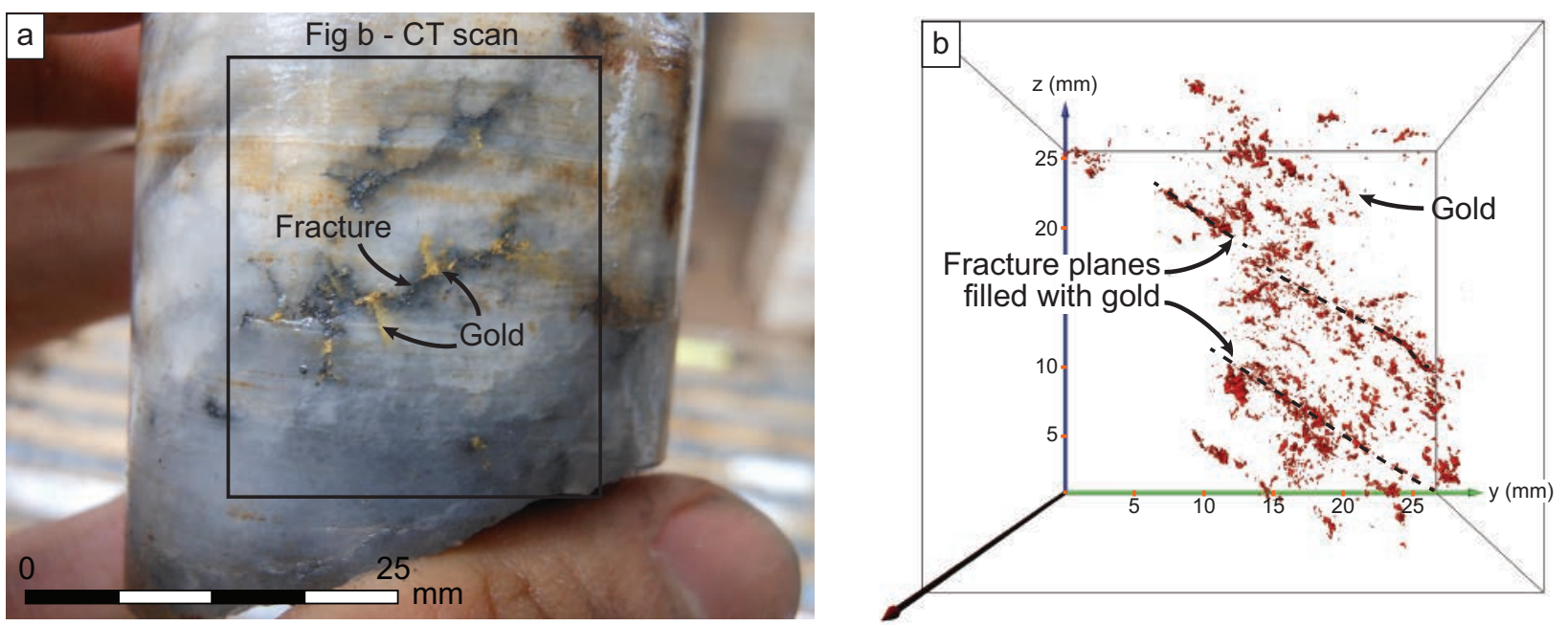

Fig. 12. a. Hand specimen of quartz hosting visible gold in fractures. b. Isosurfaces showing the three-dimensional gold distribution of gold particles as obtained using high-resolution X-ray computed tomography. Gold fills and defines fracture networks in the quartz vein. 
that (1) the first bedding-parallel fabric $S 1_{\mathrm{Ob}}$ is only poorly preserved; (2) the most dominant fabric, $\mathrm{S} 2 \mathrm{Ob}$, is striking NE, dipping steeply SE to NW, and is associated with subhorizontal stretching; (3) strain shadows surrounding gold-bearing arsenopyrite and carbonate grains formed during the development of this cleavage $(\mathrm{S} 2 \mathrm{Ob})$ and were then folded during D3 ${ }_{\mathrm{Ob}}$ (Fig. 13); (4) the $\mathrm{S} 3_{\mathrm{Ob}}$ is the last preserved pervasive foliation, striking ENE-WSW to E-W and shallowly dipping to the NNW; (5) the associated $\mathrm{F} 3 \mathrm{ob}$ fold hinges plunge $20^{\circ}$ to $50^{\circ}$ to the northeast, refold the mineralized shear zones, and correspond to the dominant high-grade ore shoot geometry at the deposit scale (group 3, Fig. 7); and (6) the large mineralized quartz veins are boudinaged during $\mathrm{D} 2 \mathrm{Ob}$ and are folded by $\mathrm{F} 3 \mathrm{Ob}$ folds, and therefore formed pre- to syn-D2 $\mathrm{Ob}$, but the gold and accessory sulfides in the veins were introduced during $\mathrm{D} 3_{\mathrm{Ob}}$.

At the underground drive scale, F3ob fold hinges also correspond to high gold grades and visible gold mineralization (Figs. 9, 10). At the microscopic scale, SEM work and the three-dimensional visualization of the distribution of gold particles in high-grade quartz vein samples using high resolution $\mathrm{X}$-ray computed tomography show that all the visible gold and accessory sulfides are located within microfracture networks overprinting the quartz veins, and that late chlorite in the wall rock is parallel with $\mathrm{S} 33_{\mathrm{ob}}$. The chlorite porphyroblasts are thus coeval with the fracture-hosted gold ores. We conclude that the gold contained in the crystal lattice of the gold-bearing arsenopyrites and the associated carbonate alteration halo formed syn-D2 $2_{\mathrm{Ob}}$. In contrast, we conclude that the visible gold mineralization and accessory sulfides in the Obuasi veins formed during $\mathrm{D} 3_{\mathrm{Ob}}$, and thus postdates the formation of the major quartz veins themselves and the sulfide mineralization in the surrounding wall rocks (Table 2; Fig. 14).

The results of this study differ from observations described by Allibone et al. (2002), Oberthür et al. (1994), and Blenkinsop et al. (1994), in providing a new model for the timing of mineralization and structural development. For example,

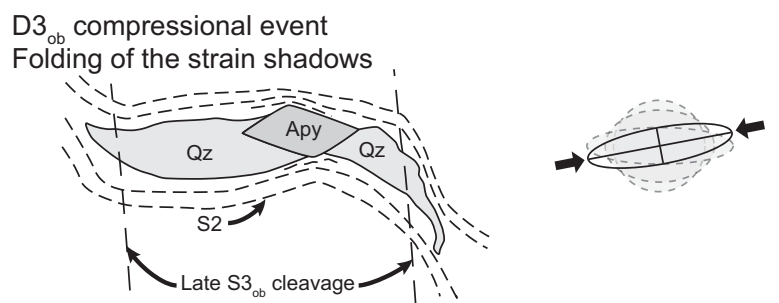

\section{D2 ${ }_{o b}$ compressional event \\ Development of the strain shadows}
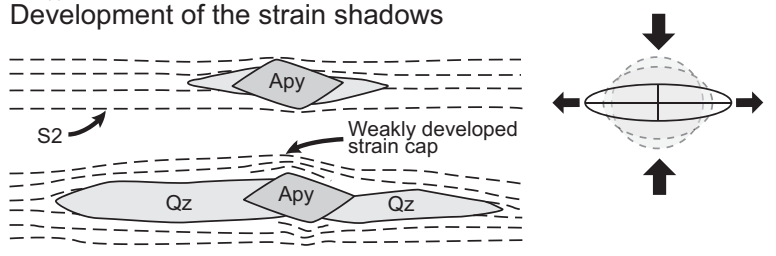

Apy crystallization syn-D2
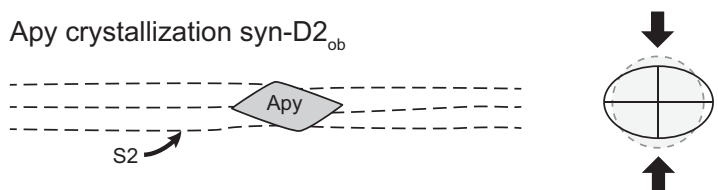

Fig. 13. Interpretation of the evolution of the strain shadows surrounding gold-bearing arsenopyrite and the associated strain ellipsoid; the arsenopyrite grains crystallize during $\mathrm{D} 2 \mathrm{Ob}$ and develop strain shadows during this period. They are later folded during $\mathrm{D} 3_{\mathrm{Ob}}$.

Oberthür et al. (1997) concluded that the refractory disseminated gold and visible gold in the veins were formed as one event, while we interpret the gold to have been formed in two distinct events. Nonetheless, this study also confirms a number of important relationships established by these latter studies (Tables 2,3). We discuss the similarities and differences in more detail below.

First, $\mathrm{D} 1_{\mathrm{Ob}}$ and $\mathrm{D} 1_{\mathrm{Al}}$ correspond with one another, although this was not reported by Blenkinsop et al. (1994), probably

Table 2. New Structural Scheme for Obuasi Integrating the Timing of Mineralization

\begin{tabular}{lcc}
\hline \hline Deformation & Representative structures & Mineralization \\
\hline $\mathrm{D} 1_{\mathrm{Ob}}$ & & \\
$\mathrm{S} 1$ rarely preserved bedding parallel shearing & - & - \\
Similar to $\mathrm{D} 1_{\mathrm{Al}}$ & & \\
\hline
\end{tabular}

D2 ${ }_{\mathrm{Ob}}, \mathrm{NW}-\mathrm{SE}$ shortening

Steeply dipping NE striking $\mathrm{S} 2_{\mathrm{Ob}}$

$\mathrm{F} 2 \mathrm{Ob}$ tight to isoclinal folding,

Large quartz veins,

Subhorizontal stretching

(boudinage, $\mathrm{BN}=$ boudin neck)

Similar to $\mathrm{D} 1_{\mathrm{Bl}}$ and $\mathrm{D} 2_{\mathrm{Al}}$
D3 ${ }_{\mathrm{Ob}}, \mathrm{NNW}$-SSE shortening

Gently dipping E to NE S3Ob

Asymmetric F3 folds

$\mathrm{F} 3 \mathrm{Ob}=30 \rightarrow 45$

Folding of the Ashanti fault

Similar to $\mathrm{D} 2 \mathrm{Bl}$ and $\mathrm{D} 4_{\mathrm{Al}}$
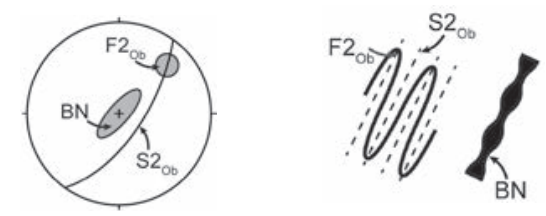

First stage mineralization

Disseminated gold-bearing sulfides (Apy, Py)

Note: The first gold event occurred during D2ob and the second during D3ob 


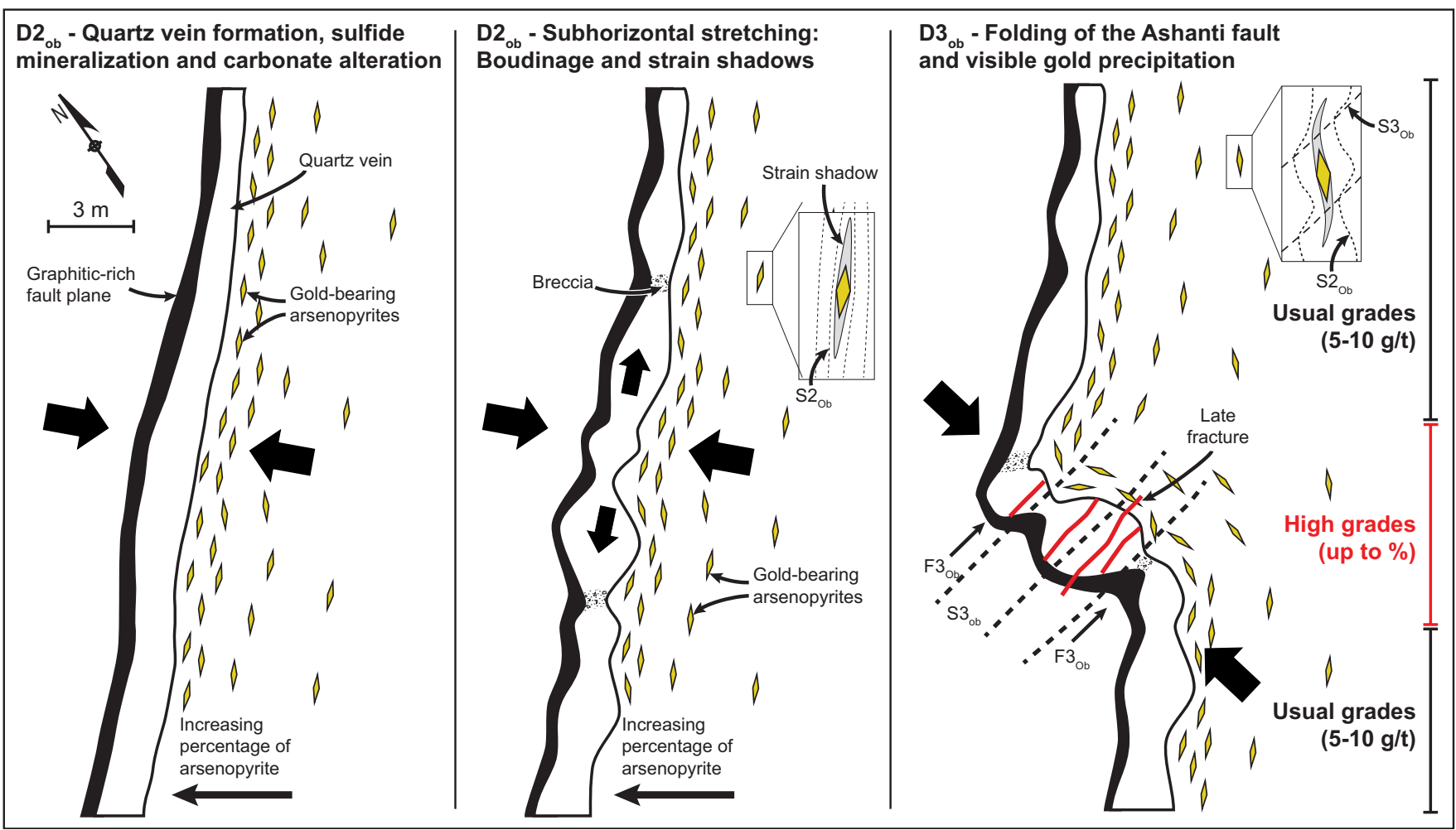

Fig. 14. Interpretation through time of the mineralizing events in Obuasi in a schematic underground map. The arsenopyrite mineralization and boudinage of the quartz vein is synchronous with $\mathrm{D} 2_{\mathrm{Ob}}$ and stretching, the visible gold mineralization overprints the quartz vein in the $\mathrm{F} 3 \mathrm{Ob}$ fold hinges.

Table 3. Comparison of Structural Evolution Outlined in This Study with Compilation of Previous Structural Studies of Obuasi (Blenkinsop et al., 1994; Allibone et al., 2002) and Regional Interpretation (Miller et al., unpub. data)

\begin{tabular}{l} 
This study \\
Obuasi \\
\hline D1 ob \\
S1 $1_{\text {Ob rarely preserved bedding }}$ \\
parallel shearing
\end{tabular}

D2 ${ }_{\mathrm{Ob}}, \mathrm{NW}$-SE shortening

$\mathrm{S} 22_{\mathrm{Ob}}$ steep easterly dipping NE-SW

F2 2 ob asymmetric folding

Large quartz veins

NE-SW subhorizontal stretching

and boudinage

Gold-bearing sulfide mineralization

Blenkinsop et al. (1994)

Obuasi

Allibone et al. (2002)

Obuasi

$\mathrm{D} 1_{\mathrm{Al}}$

$\mathrm{S} 1_{\mathrm{Al}}$ rarely preserved bedding parallel shearing

$\mathrm{D} 1_{\mathrm{Bl}}, \mathrm{NW}-\mathrm{SE}$ shortening $\mathrm{S} 1_{\mathrm{Bl}}$ subvertical cleavage

NE-SW cylindrical folding

D2 $2_{\mathrm{Al}}, \mathrm{NW}$-SE shortening

Isoclinal folds with axial surface

parallel to the regional faults and

shear zones

Ashanti thrust fault

$\mathrm{D} 3_{\mathrm{Al}}$

Low dip axial surface fold at Obuasi

$S 3_{\mathrm{Al}} \mathrm{NE}$ crenulation cleavage

overprinting $\mathrm{S} 2_{\mathrm{Al}}$

D3 $\mathrm{Ob}, \mathrm{NNW}-\mathrm{SSE}$ shortening

$\mathrm{S} 3_{\mathrm{Ob}}$ overprinting cleavage $\mathrm{E}$ to $\mathrm{NE}$

Crosscutting folding plunging $50^{\circ}$

to $30^{\circ}$ to the NE

Folding of the Ashanti fault

High-grade visible gold mineralization
$\mathrm{D} 2_{\mathrm{Bl}}$, NNE-SSW shortening

$\mathrm{S} 2_{\mathrm{Bl}}$ variable orientation

(E-W to NNW-SSE),

gently dipping to the $\mathrm{NE}$
D4 ${ }_{\mathrm{Al}}, \mathrm{NNW}-\mathrm{SSE}$ shortening

Steeply plunging upright folds

$\left(\mathrm{F} 4_{\mathrm{Al}}\right)$ developed on the western side of the shear

$\mathrm{D} 5_{\mathrm{Al}}$ or late-D4 $4_{\mathrm{Al}}$

Sinistral strike-slip faults and shearing

Large quartz veins and gold

mineralization
D3 ${ }_{\mathrm{Gh}}, \mathrm{NW}-\mathrm{SE}$ shortening

$\mathrm{S} 3{ }_{\mathrm{Gh}}$ subvertical cleavage NE-SW

Thrust faults (Ashanti, Damang, ...)

D4 $4_{\mathrm{Gh}}, \mathrm{NNW-SSE}$ shortening

Sinistral shear reactivation of

D3 $3_{\mathrm{Gh}}$ thrust

$\mathrm{S} 4_{\mathrm{Gh}}$ crenulation cleavage

ENE-WSW

Greenschist retrograde metamorphism 
due to poor preservation of the deformation in the rocks. The defined $\mathrm{D} 2 \mathrm{Ob}, \mathrm{D} 2_{\mathrm{Al}}$, and $\mathrm{D} 1_{\mathrm{Bl}}$ episodes most likely represent the same event, where strain was accommodated by pervasive flattening and stretching, and localized high strain along shear zones. The $\mathrm{D} 3_{\mathrm{Ob}}, \mathrm{D} 4_{\mathrm{Al}}$, and $\mathrm{D} 2_{\mathrm{Bl}}$ episodes also represent the same structural event, which is characterized by refolding of the shear zones. Allibone et al. (2002) reported a further weakly developed flat-lying $\left(\mathrm{S}_{\mathrm{Al}}\right)$ cleavage striking $\mathrm{NE}$. However, this cleavage was not observed in this study, nor by Blenkinsop et al. (1994), which may indicate that this cleavage is not a pervasive fabric across the district and is most likely the product of localized deformation, rather than a distinct regional tectonic event.

Second, with regards to ore shoot controls, the significance of fault intersections and volcanic units was identified by Allibone et al. (2002) and by this study. The ore shoot group controlled by the late folding (F3Ob) was identified by all studies, although Blenkinsop et al. (1994) and Oberthür et al. (1994) did not distinguish between fold generations.

Third, with regards to the timing of arsenopyrite growth, Oberthür et al. (1994) reported that the preferred orientation of the gold-bearing arsenopyrite in the wall rocks is commonly parallel to $\mathrm{S} 2 \mathrm{Ob}$, which is in agreement with this study. Junner (1932) also documented that the arsenopyrite at Obuasi was fringed by "fibrous quartz" and provided a photomicrograph demonstrating folding of these quartz fringes (Junner, 1932, fig. 4). In contrast, Allibone et al. (2002) reported arsenopyrite needles in the wall rocks overprinting the S3ob cleavage and interpreted the bulk of the sulfide mineralization disseminated in the sediments to postdate D $3_{\mathrm{Ob}}$. However, from our analysis, in approximately $50 \%$ of thin sections examined from the mineralized wall rocks, 80 to $90 \%$ of the arsenopyrite grains have strain shadows developed during D2 $\mathrm{Ob}$. We also found specimens without strain shadows correlated with coarser grained sedimentary rocks, reflecting a lithologic control rather than a difference in timing. As such, we conclude that the timing of the majority of the gold-bearing arsenopyrite disseminated in the wall rocks is syn-D2 0 .

Fourth, Allibone et al. (2002) reported large, mineralized quartz vein arrays that were interpreted to form during late sinistral strike-slip movement on the shear zones (late-D $4_{\mathrm{Al}}$ to D5 ${ }_{\mathrm{Al}}$, in Allibone et al., 2002). The sinistral shear vein arrays were attributed to a late event of wrench tectonics operating at brittle-ductile conditions, and postdating our D3ob during the main NNW-SSE compression. Conversely, in this study we report that thick mineralized quartz veins have been symmetrically boudinaged and dynamically recrystallized, indicating that they were deformed during $\mathrm{D} 2 \mathrm{Ob}$ and therefore formed pre- to syn-D2 2 . Arrays of sinistral shear veins, as reported by Allibone et al. (2002), were not observed in the highly mineralized ore zones in this study or by Blenkinsop et al. (1994). We suggest the shear vein arrays observed by Allibone et al. (2002) correspond to late, localized, sinistral strike-slip movement (e.g., Ashanti fissure), but that such an event is not expressed pervasively across the deposit and reflects a minor control on vein-hosted mineralization for the whole deposit.

The Allibone et al. (2002) model attributed the timing of gold mineralization to the late sinistral reactivation of the Ashanti fault system during late-D $4_{\mathrm{Al}}$ to $\mathrm{D} 5_{\mathrm{Al}}$. This interpretation is based on (1) the description of veins showing sinistral kinematics during their formation, (2) the orebody geometry with flexure $(\mathrm{F} 3 \mathrm{Ob})$ of the shear zones acting as dilational or compressional jogs during strike-slip movement, (3) slickenlines on faults and surfaces of veins, and (4) acicular arsenopyrite grains overprinting the late $\mathrm{S} 3 \mathrm{Ob}$ cleavage.

Converse to Allibone et al. (2002), Oberthür et al. (1994) and Blenkinsop et al. (1994) interpreted the two mineralization styles as the product of a single progressive event during $\mathrm{D} 1_{\mathrm{Bl}} / \mathrm{D} 2_{\mathrm{Bl}}$, with the varying styles related to deformation occurring under different pressure-temperature-strain rate conditions. Initially the gold-bearing sulfides are introduced in a ductile regime while, as the system evolves, the quartz veins and visible gold are deposited in a more brittle regime. This model is based on (1) the chemical association being different between the two styles of mineralization, with an As-S$\mathrm{Au}$ signature developing initially and a polymetallic signature developing in the later stages; (2) sulfidized rock fragments in the quartz veins; and (3) the apparent contrast of ductile versus brittle textures.

In contrast to these two models, we summarize the timing of mineralization as follows (Table 2; Fig. 14). First, quartz veins, with gold-bearing sulfides in surrounding wall rocks, formed syn-D2 $\mathrm{Ob}$. The sulfides are the product of sulfidation of the wall rock due to a pervasive infiltration of fluid through the metasedimentary rocks. Second, stretching of the quartz veins and crystallization of strain shadows surrounding the sulfides occurred later during the D2 $2_{\mathrm{Ob}}$ event. Finally, folding of the quartz veins, and syn-D 3 ob precipitation of visible gold with accessory sulfides in fractures, created high-grade ore shoots in fold hinges plus crenulation of the D2 $2_{\mathrm{Ob}}$ strain shadows surrounding sulfide and carbonate grains. Thus, this study reports that economic mineralization in the Obuasi deposit developed during at least two separate structural events. Furthermore, considering the results of Allibone et al. (2002) in the context of this study, a potential third minor mineralizing event may exist in parts of the Obuasi deposit. This event is limited to a small amount of arsenopyrite grains overprinting the $\mathrm{S} 3 \mathrm{Ob}$ cleavage and gold veining in localized areas of the Obuasi deposit and district (e.g., Bekansi and Kotopre prospects).

\section{Evidence for multiple stages of mineralization in the Birimian terranes of West Africa and worldwide}

The Birimian terranes are unusually well endowed and contain a number of world-class deposits (>6 Moz as defined by Schodde and Hronsky, 2006), including Sadiola, Morilla, Syama, Siguiri, Damang, Prestea, and Tarkwa (e.g., McFarlane et al., 2011; Perrouty et al., 2012 ; Masurel et al., 2017; Lebrun et al., 2017). It has been demonstrated in this study that the Obuasi gold deposit formed mainly during two mineralizing events. Although the two events are distinct, they both likely occurred during the second cycle of the Eburnean orogeny, with the early stage of mineralization constrained by $\mathrm{U} / \mathrm{Pb}$ zircon ages of the Anyankyerem granite to younger than $2105 \pm 2 \mathrm{Ma}$ (Oberthür et al., 1998) and hydrothermal rutile from the Yaw Mensakrom deposit at $2098 \pm 7$ Ma, while Le Mignot et al. (2017) reported an Re-Os age of $2040 \pm 87 \mathrm{Ma}$ for disseminated gold-bearing arsenopyrite. As such, this raises the question as to whether there is also evidence for 
multiple episodes of mineralization across the Ashanti belt. In the Ashanti greenstone belt, several economic gold mineralizing events have been described (Parra-Avila et al., in press; Miller et al., unpub. data). The oldest lode gold event is bracketed at the Wassa/Benso system between $2192.7 \pm$ 4.6 and $2159.5 \pm 7.5 \mathrm{Ma}$ (Luis Parra et al., 2016) and it has been suggested that Wassa-like deposits could represent a possible source for the Tarkwa paleoplacer deposits, such as the 41-Moz Au Tarkwa deposit (Perrouty et al., 2012). The Tarkwa paleoplacer deposit was deformed during the main NW-SE shortening $\left(\mathrm{D} 2_{\mathrm{Ob}}\right)$, which is broadly at the same time as the first sulfide mineralization event at Obuasi, indicating that Obuasi is an unlikely source for the detrital gold in the Tarkwaian basin (Milési et al., 1991). Finally, mineralization at the Damang orogenic lode-gold system, which overprints the Tarkwa paleoplacer, has been dated (U/Pb on hydrothermal xenotime) at $2063 \pm 9 \mathrm{Ma}$ (Pigois et al., 2003) and consequently represents a late gold episode in the Ashanti belt. In summary, it appears that the West African Birimian terranes have been affected by multiple mineralizing events and a minimum of two, and possibly three, separate events are expressed in the one deposit at Obuasi.

Worldwide, many giant orogenic gold deposits have experienced multiple stages of successive, nevertheless different, mineralization episodes in the same location over time (McCuaig et al., 2001; Bucci et al., 2004; Kolb et al., 2005; Robert et al., 2005; Bateman et al., 2008). By way of example, the giant Western Australia Kalgoorlie gold deposit (consisting of Golden Mile and Mount Charlotte mineralization) contains evidence of at least two mineralizing events. Field relationships indicate that the vein stockwork and associated goldbearing pyrites in the wall rock of the Mount Charlotte-type mineralization overprints the shear zone-hosted gold of the Golden Mile (native gold and Ag-Au telluride Fimiston and Oroya lodes). Differences between the two styles of mineralization include ore mineral assemblages, wall-rock alteration styles, wall-rock fabrics, and P-T conditions (Bateman and Hagemann, 2004; Gauthier et al., 2007; Mueller and Muhling, 2013; Mueller, 2014). Bateman and Hagemann (2004) concluded that at least two distinct episodes of mineralization took place in this giant gold deposit, and it has subsequently become clear that these events occurred within a geochronological period of approximately 25 Myrs of each other (Vielreicher et al., 2010).

Other examples of large gold deposits and districts formed by multiple events, include the Val-d'Or goldfields (Abitibi, Canada: Couture et al., 1994), the Hutti gold deposit (Dharwar craton, India: Kolb et al., 2005), the Red Lake deposit (Ontario, Canada: Dubé et al., 2004) and the Bendigo-Ballarat goldfields (central Victoria, Australia: Bierlein et al., 1999; Wilson et al., 2013). In the Val-d'Or goldfields, the deposits have been classified into two categories, "young" undeformed deposits deposited subsequent to $2630 \mathrm{Ma}$ (Sigma, Lamaque, Camflo, Perron, and Béliveau) and "older" polydeformed deposits deposited prior to $2690 \mathrm{Ma}$ (Siscoe, Kiena, Orion, and Norlartic mines), thus demonstrating that at least two distinct major gold mineralizing events occurred there (Couture et al., 1994). The Hutti gold deposit formed during two successive tectonic events with different structural controls, alteration, and ore signatures, at different P-T conditions
(Kolb et al., 2005). The early stage is characterized by disseminated mineralization associated with sulfides and the late stage is defined by visible gold in laminated quartz veins (Kolb et al., 2005). At the Red Lake deposit, the high-grade mineralization, comprising arsenopyrite and visible gold, occurred before $2712 \mathrm{Ma}$ and a second, less significant stage of visible gold mineralization occurred after $2702 \mathrm{Ma}$ (U-Pb on zircons; Dubé et al., 2004). The Bendigo-Ballarat goldfields underwent an initial mineralization episode between 460 and 440 Ma (hydrothermally altered whole-rock Ar/Ar), followed by a second episode of mineralization between 410 and $380 \mathrm{Ma}$ (Ar/Ar on hydrothermal muscovite separates; Bierlein et al., 1999). Similar to the Obuasi deposit, the Bendigo deposit in the Bendigo-Ballarat goldfields comprises early wall-rock disseminated sulfide mineralization and later vein hosted visible gold (Wilson et al., 2013).

The conclusion that multiple events are responsible for gold mineralization in Obuasi and other deposits around the world raises the question, critical for exploration, of whether metal introduced in the first mineralizing event is remobilized, or if new batches of gold are added to the deposits in subsequent mineralizing events. In the Ashanti belt, both potential mechanisms have been invoked. Oberthür et al. (1997) briefly argued that the preserved textures of gold zonation in arsenopyrite suggest that remobilization did not occur. In contrast, Mumin et al. (1994) developed a model of gold remobilization from pyrite and arsenopyrite, for the Bogosu-Prestea mining district, based on gold zonation textures using ion probe and EPMA data.

\section{Conclusions}

In this study we have identified a three-stage structural sequence consisting of $\mathrm{Dl}_{\mathrm{Ob}}$ defined as bedding parallel shearing and only weakly recorded in the rock fabric, the main $\mathrm{D} 2_{\mathrm{Ob}} \mathrm{NW}-\mathrm{SE}$ shortening event, and, finally, a N-S to NW-SE shortening event $\left(\mathrm{D} 3_{\mathrm{Ob}}\right)$. Two spatially and temporally distinct styles of mineralization are clearly identified, gold-bearing arsenopyrite that is disseminated in metasedimentary rocks and gold in fractures in thick quartz veins. The gold-rich arsenopyrite ores precipitated synchronously with isoclinal folding, $\mathrm{S} 2_{\mathrm{Ob}}$ foliation development, and foliation parallel stretching during $\mathrm{D} 22_{\mathrm{Ob}}$, and are associated with a 25- to $50-\mathrm{m}$ ankerite and siderite alteration halo.

In contrast, using a combination of high-resolution X-ray computed tomography and SEM, native gold, associated locally with extremely high grades, fills fractures in the quartz veins. These form high-grade ore shoots that are located in F3ob fold hinges. Thus, mineralization hosted by thick, boudinaged quartz veins was controlled by later fracturing and folding of the quartz veins during D3ob. Chlorite porphyroblasts overprinting the $\mathrm{S} 33_{\mathrm{Ob}}$ cleavage represent the proximal alteration of the quartz vein ores.

In summary, the results of this study indicate that the Obuasi giant gold deposit formed mainly during two episodes of mineralization, marked by differences in style of mineralization and structural control. It is not yet known whether the two events are the products of two distinct hydrothermal events as has been interpreted in other giant deposits, for example, Golden Mile, Boddington, or Ballarat (Bierlein et al., 1999; McCuaig et al., 2001; Bateman and Hagemann, 2004), or if 
the visible gold ore in the quartz veins is the product of gold remobilization from the disseminated ore.

\section{Acknowledgments}

This study is part of Denis Fougerouse's Ph.D. research at the Centre for Exploration Targeting, University of Western Australia. AngloGold Ashanti is acknowledged for financial support and field logistic assistance. This study greatly benefited from discussions with Thomas Oberthür. Micklethwaite was funded by the Hammond-Nisbet Fellowship. $\mathrm{McCu}-$ aig and Miller acknowledge receipt of a large ARC linkage LP110100667. The authors are thankful for the scientific and technical assistance of Janet Muhling and the Australian Microscopy and Microanalysis Research Facility at the Centre for Microscopy, Characterisation and Analysis, University of Western Australia, a facility funded by the University, State and Commonwealth Governments. The most helpful reviews of Andrew Allibone and Thomas Blenkinsop are gratefully acknowledged. This is contribution (635) from the ARC Centre of Excellence for Core to Crust Fluid Systems (http:// www.ccfs.mq.edu.au).

\section{REFERENCES}

Adadey, K., Clarke, B., Théveniaut, H., Urien, P., Delor, C., Roig, J., and Feybesse, J., 2009, Geological map explanation-Map sheet 0503 B (1:100 000), CGS/BRGM/Geoman: Geological Survey Department of Ghana (GSD) $\mathrm{MSSP} / 2005 / \mathrm{GSD} / 5 \mathrm{a}$.

Allibone, A.H., McCuaig, T.C., Harris, D., Etheridge, M., Munroe, S., Byrne, D., Amanor, J., and Gyapong, W., 2002, Structural controls on gold mineralization at the Ashanti gold deposit, Obuasi, Ghana: Society of Economic Geologists Special Publication 9, p. 29.

Amanor, J., 1979, The geology of Ashanti gold mines and implications for exploration: M.Sc. dissertation, London, UK, Royal School of Mines, 91 p. AngloGold-Ashanti, 2014, Mineral resource and ore reserve report.

Bateman, R., and Hagemann, S., 2004, Gold mineralisation throughout about 45Ma of Archaean orogenesis: Protracted flux of gold in the Golden Mile, Yilgarn craton, Western Australia: Mineralium Deposita, v. 39, p. 536-559.

Bateman, R., Ayer, J.A., and Dubé, B., 2008, The Timmins-Porcupine gold camp, Ontario: Anatomy of an Archean greenstone belt and ontogeny of gold mineralization: Economic Geology, v. 103, p. 1285-1308.

Bierlein, F.P., Foster, D.A., McKnight, S., and Arne, D.C., 1999, Timing of gold mineralisation in the Ballarat goldfields, central Victoria: Constraints from ${ }^{40} \mathrm{Ar} /{ }^{39} \mathrm{Ar}$ results: Australian Journal of Earth Sciences, v. 46, p. 301-309.

Blenkinsop, T., Schmidt Mumm, A., Kumi, R., and Sangmor, S., 1994, Structural geology of the Ashanti gold mine: Geologisches Jahrbuch D, v. 100, p. 131-153.

Bowell, R.J., 1994, Sulfide oxidation and production of gossans, Ashanti mine, Ghana: International Geology Review, v. 36, p. 732-752.

Bowell, R., Foster, R., and Stanley, C., 1990, Telluride mineralization at Ashanti gold mine, Ghana: Mineralogical Magazine, v. 54, p. 617-627.

Bucci, L.A., McNaughton, N.J., Fletcher, I.R., Groves, D.I., Kositcin, N., Stein, H.J., and Hagemann, S.G., 2004, Timing and duration of high-temperature gold mineralization and spatially associated granitoid magmatism at Chalice, Yilgarn craton, Western Australia: Economic Geology, v. 99, p. 1123-1144

Couture, J.-F., Pilote, P., Machado, N., and Desrochers, J.-P., 1994, Timing of gold mineralization in the Val-d'Or district, southern Abitibi belt: Evidence for two distinct mineralizing events: Economic Geology, v. 89, p. 1542-1551.

Davis, D.W., Hirdes, W., Schaltegger, U., and Nunoo, E.A., 1994, U/Pb age constraints on deposition and provenance of Birimian and gold-bearing Tarkwaian sediments in Ghana, West Africa: Precambrian Research, v. 67, p. 89-107.

Dubé, B., Williamson, K., Mcnicoll, V., Malo, M., Skulski, T., Twomey, T., and Sanborn-Barrie, M., 2004, Timing of gold mineralization at Red Lake, Northwestern Ontario, Canada: New constraints from U-Pb geochronology at the Goldcorp high-grade zone, Red Lake mine, and the Madsen mine: Economic Geology, v. 99, p. 1611-1641.
Feybesse, J.-L., Billa, M., Guerrot, C., Duguey, E., Lescuyer, J.-L., Milesi, J.-P., and Bouchot, V., 2006, The paleoproterozoic Ghanaian province: Geodynamic model and ore controls, including regional stress modeling: Precambrian Research, v. 149, p. 149-196.

Fougerouse, D., Micklethwaite, S., Ulrich, S., Miller, J., and McCuaig, T.C. 2013, Multistage mineralization of the Obuasi giant gold deposit, Ghana: Biennial SGA Meeting, 12 $2^{\text {th }}, 12-15$ August 2013, Uppsala, Sweden, Proceedings, v. 3, p. 1105-1108.

Gauthier, L., Hagemann, S., and Robert, F., 2007, The geological setting of the Golden Mile gold deposit, Kalgoorlie, WA: Geoscience Australia Record, v. 14, p. 181-185.

Godel, B., 2013, High-resolution X-ray computed tomography and its application to ore deposits: From data acquisition to quantitative threedimensional measurements with case studies from Ni-Cu-PGE deposits: Economic Geology, v. 108, p. 2005-2019.

Gyapong, W., 1980, Factors controlling ore localization at Ashanti mine, Ghana: M.Sc. thesis, London, UK, Imperial College, 103 p.

Höhndorf, A., Oberthür, T., Gast, L., Vetter, U., and Mumm, A.S., 1994, Lead isotope systematics of the mineralization at the Ashanti gold mine, Obuasi, Ghana: Geologische Jahrbuch, D, v. 100, p. 155-165.

John, T., Klemd, R., Hirdes, W., and Loh, G., 1999, The metamorphic evolution of the Paleoproterozoic (Birimian) volcanic Ashanti belt (Ghana, West Africa): Precambrian Research, v. 98, p. 11-30.

Junner, N.R., 1932, The geology of the Obuasi goldfield: Gold Coast Geological Survey Memoir, v. 2, 43 p.

1935, Gold in the Gold Coast: Gold Coast Geological Survey Memoir v. 4,67 p.

Klemd, R., Hünken, U., and Olesch, M., 1996, Fluid composition and source of early Proterozoic lode gold deposits of the Birimian volcanic belt, West Africa: International Geology Review, v. 38, p. 22-32.

Kolb, J., Rogers, A., and Meyer, F.M., 2005, Relative timing of deformation and two-stage gold mineralization at the Hutti mine, Dharwar craton, Indic: Mineralium Deposita, v. 40, p. 156-174.

Lebrun, E., Miller, J., Thébaud, N., Ulrich, S., and McCuaig, T.C., 2017, Structural controls on an orogenic gold system: The world-class Siguiri gold district, Siguiri Basin, Guinea, West Africa: Economic Geology, v. 112, p. 73-98.

Le Mignot, E., Reisberg, L., André-Mayer, A.-S., Bourassa, Y., and Miller, J., 2016, Re-Os geochronological evidence for multiple Paleoproterozoic gold events at the scale of the West African craton: Economic Geology, v. 112 p. $145-168$.

Leube, A., Hirdes, W., Mauer, R., and Kesse, G.O., 1990, The early Proterozoic Birimian Supergroup of Ghana and some aspects of its associated gold mineralization: Precambrian Research, v. 46, p. 139-165.

Masurel, Q., Thébaud, N., Miller, J., Ulrich, S., Hein, K.A.A., Cameron, G., Beziat, D., Bruguier, O., and Davis, J.A., 2017, Sadiola Hill: A worldclass carbonate-hosted gold deposit in the Birimian terranes of Mali, West Africa: Economic Geology, v. 112, p. 23-47.

McCuaig, T., Behn, M., Stein, H., Hagemann, S., McNaughton, N., Cassidy, K., Champion, D., and Wyborn, L., 2001, The Boddington gold mine [ext. abs.]: A new style of Archaean $\mathrm{Au}-\mathrm{Cu}$ deposit: International Archaean Symposium, $4^{\text {th }}$, Extended Abstracts, Record-Australian Geological Survey Organization, v. 37 , p. $453-455$.

McFarlane, C.R.M., Mavrogenes, J., Lentz, D., King, K., Allibone, A., and Holcombe, R., 2011, Geology and intrusion-related affinity of the Morila gold mine, southeast Mali: Economic Geology, v. 106, p. 727-750.

Milési, J.P., Ledru, P., Ankrah, P., Johan, V., Marcoux, E., and Vinchon, C., 1991, The metallogenic relationship between Birimian and Tarkwaian gold deposits in Ghana: Mineralium Deposita, v. 26, p. 228-238.

Morey, A.A., Tomkins, A.G., Bierlein, F.P., Weinberg, R.F., and Davidson, G.J., 2008, Bimodal distribution of gold in pyrite and arsenopyrite: Examples from the Archean Boorara and Bardoc shear systems, Yilgarn craton, Western Australia: Economic Geology, v. 103, p. 599-614.

Mueller, A., 2014, Structure, alteration, and geochemistry of the Charlotte quartz vein stockwork, Mt. Charlotte gold mine, Kalgoorlie, Australia: Time constraints, down-plunge zonation, and fluid source: Mineralium Deposita, v. 49 , p. $1-24$.

Mueller, A., and Muhling, J., 2013, Silver-rich telluride mineralization at Mount Charlotte and Au-Ag zonation in the giant Golden Mile deposit, Kalgoorlie, Western Australia: Mineralium Deposita, v. 48, p. 295-311.

Mumin, A.H., Fleet, M.E., and Chryssoulis, S.L., 1994, Gold mineralization in As-rich mesothermal gold ores of the Bogosu-Prestea mining district of the Ashanti gold belt, Ghana: Remobilization of "invisible" gold: Mineralium Deposita, v. 29, p. 445-460. 
Mumm, A.S., Oberthür, T., Vetter, U., and Blenkinsop, T.G., 1997, High $\mathrm{CO}_{2}$ content of fluid inclusions in gold mineralisations in the Ashanti belt, Ghana: A new category of ore forming fluids?: Mineralium Deposita, v. 32, p. 107-118.

Oberthür, T., Vetter, U., Schmidt Mumm, A., Weiser, T., Amanor, J., Gyapong, W., Kumi, R., and Blenkinsop, T., 1994, The Ashanti gold mine at Obuasi, Ghana: Mineralogical, geochemical, stable isotope and fluid inclusion studies on the metallogenesis of the deposit: Geologisches Jahrbuch D, v. 100, p. 31-129.

Oberthür, T., Weiser, T., Amanor, J.A., and Chryssoulis, S.L., 1997, Mineralogical siting and distribution of gold in quartz veins and sulfide ores of the Ashanti mine and other deposits in the Ashanti belt of Ghana: Genetic implications: Mineralium Deposita, v. 32, p. 2-15.

Oberthür, T., Vetter, U., Davis, D.W., and Amanor, J.A., 1998, Age constraints on gold mineralization and Paleoproterozoic crustal evolution in the Ashanti belt of southern Ghana: Precambrian Research, v. 89, p. 129-143.

Parra-Avila, L., Bourassa, Y., Miller, J., Perrouty, S., Fiorentini, M.L., and McCuaig, T.C., in press, Age constraints of the Wassa and Benso mesothermal gold deposits, Ashanti belt, Ghana, West Africa: South African Journal of Science.

Passchier, C.W., and Trouw, R.A., 2005, Microtectonics: Berlin, Springer, $382 \mathrm{p}$.

Perrouty, S., Aillères, L., Jessell, M.W., Baratoux, L., Bourassa, Y., and Crawford, B., 2012, Revised Eburnean geodynamic evolution of the gold-rich southern Ashanti belt, Ghana, with new field and geophysical evidence of pre-Tarkwaian deformations: Precambrian Research, v. 204-205, p. 12-39.

Pigois, J.-P., Groves, D., Fletcher, I., McNaughton, N., and Snee, L., 2003, Age constraints on Tarkwaian palaeoplacer and lode-gold formation in the Tarkwa-Damang district, SW Ghana: Mineralium Deposita, v. 38, p. $695-714$.
Robert, F., Poulsen, K.H., Cassidy, K.F., and Hodgson, C.J., 2005, Gold metallogeny of the Superior and Yilgarn cratons: Economic Geology 100 ${ }^{\text {th }}$ Anniversary Volume, p. 1001-1034.

Schodde, R., and Hronsky, J., 2006, The role of world-class mines in wealth creation: Society of Economic Geologists Special Publication 12, p. 71.

Schwartz, M.O., Oberthür, T., Amanor, J., and Gyapong, W.A., 1992, Fluid inclusion re-equilibration and $\mathrm{P}-\mathrm{T}-\mathrm{X}$ constraints on fluid evolution in the Ashanti gold deposit, Ghana: European Journal of Mineralogy, v. 4, p. 1017-1033.

Vielreicher, N.M., Groves, D.I., Snee, L.W., Fletcher, I.R., and McNaughton, N.J., 2010, Broad synchroneity of three gold mineralization styles in the Kalgoorlie gold field: SHRIMP, U-Pb, and ${ }^{40} \mathrm{Ar} /{ }^{39} \mathrm{Ar}$ geochronological evidence: Economic Geology, v. 105, p. 187-227.

Walsh, J.J., Watterson, J., Bailey, W.R., and Childs, C., 1999, Fault relays, bends and branch-lines: Journal of Structural Geology, v. 21, p. 1019-1026.

Wilson, C.J.L., Schaubs, P.M., and Leader, L.D., 2013, Mineral precipitation in the quartz reefs of the Bendigo gold deposit, Victoria, Australia: Economic Geology, v. 108, p. 259-278.

Wilson, I., 1972, Geochemistry of alteration at the Ashanti mine: Unpublished Ph.D. thesis, University of Leeds, 254 p.

Yao, Y., and Robb, L.J., 2000, Gold mineralization in Palaeoproterozoic granitoids at Obuasi, Ashanti region, Ghana: Ore geology, geochemistry and fluid characteristics: South African Journal of Geology, v. 103, p. 255-278.

Yao, Y., Murphy, P.J., and Robb, L.J., 2001, Fluid characteristics of granitoidhosted gold deposits in the Birimian terrane of Ghana: A fluid inclusion microthermometric and Raman spectroscopic study: Economic Geology, v. 96, p. 1611-1643. 